\title{
ECOLOGY, ZOOGEOGRAPHY AND TAXONOMY OF THE \\ LOWER RIO GRANDE VALLEY MESOSTENINES (HYMENOPTERA, ICHNEUMONIDAE)
}

\author{
By Charles C. Porter ${ }^{1}$ \\ Department of Biological Sciences, Fordham University \\ Bronx, N.Y. 10458

\section{INTRODUCTION}

This study analyzes results of five years' fieldwork with net and Malaise Traps on mesostenine ichneumonids of semiarid subtropical scrub and moist gallery woods habitats in the Lower Río Grande Valley of south Texas. It lists 18 genera and 35 species. The genus Bicristella and the species Trachysphyrus mesorufus, Cryptanura lamentaria, and Lymeon leucosoma are recorded for the first time from the United States. Cryptanura vallis Mesostenus opuntiae, Bricristella texana, Diapetimorpha sphenos, D. aspila, and D. pareia are described as new. The zoogeographic relationships, phaenology, and habitat preferences of each taxon are recorded and conclusions are adduced as to distributional patterns, annual cycles, habitat selection, and diversity of the entire south Texas mesostenine fauna. The south Texas fauna also is compared with mesostenine communities of other semiarid parts of the Neotropics, such as the Peruvian Coastal Desert and the northwest Argentine Subandino, and all these relict or marginal xerophilic faunas are discussed with regard to their origin in wet forest centers of ichneumonid radiation.

\section{ACKNOWLEDGEMENTS}

Major support for this research was provided in 1976-'77 by a National Science Foundation Grant (DEB 75-22426) and during 1973-'75 by grants from the Committee for Research and Exploration of the National Geographic Society. Mr. David Riskind and Mr. Sim Oefinger, Jr. of the Texas Parks and Wildlife Department issued permits for insect collecting in the Bentsen Río Grande Valley State Park. At Bentsen Park, Mr. Reynaldo Ortíz (Superintendent)

\footnotetext{
'Research Associate, Florida State Collection of Arthropods, Florida Department of Agriculture and Consumer Services, Gainesville, Florida 32602.

Manuscript received by the editor, May 24, 1977
} 
and Mr. Antonio Salinas (Park Ranger 3) maintained the Malaise Trap used in my 1976 survey and provided cordial assistance on all my visits to the park. Mrs. Vivian Thacker, as trustee of the Valley Botanical Garden, facilitated collecting in that small but important island of natural vegetation. My father, Mr. Carroll B. Porter, also assisted in the Malaise project and in many other ways. Mr. Charles W. Calmbacher of Fordham University prepared and labeled most of the Malaise samples from Bentsen Park. Finally, Dr. Henry K. Townes of the American Entomological Institute loaned several homotypes which helped resolve crucial taxonomic problems.

\section{MATERIALS AND METHODS}

Hand collecting with a strong but light net obtained $63 \%$ of the 679 specimens captured between May 1973 and March 1977 for use in this study. Sweeping undergrowth yielded numerous mesostenines but many others were netted individually in flight from foliage. Periods annually available for fieldwork included 25 August to 9 September, 18 December to 25 January, 11-21 March (1-8 April in 1975) and 16 May to 10 June. I was in the field 7 days a week and 6-8 hours per day during all visits to south Texas.

To obtain a more comprehensive picture of mesostenine diversity than would have been possible by hand collecting alone, I employed two Malaise Traps during this research. The first was installed at the Valley Botanical Garden in a Celtis lindheimeri-C. pallida thicket and functioned from September 1973 until March 1974 but was stolen in April 1974. The second was set up under a large Pithecellobium flexicaule in deep woods near a lake at the Bentsen Río Grande Valley State Park and, having already furnished a complete series of samples for 1976, continues to operate during 1977. In both traps, a pint mason jar filled with $70 \%$ isopropyl alcohol (commercial rubbing alcohol) was used as the collecting recipient. The trap at the Botanical Garden was changed once a month but I was able to arrange for twice monthly curating of the Bentsen Park trap. Both Malaise Traps were of the "light weight" variety, as perfected by Dr. Henry K. Townes (Townes, 1972, p. 239-247).

\section{THE STUDY AREA}

The Lower Río Grande Valley is an alluvial plain that extends along the Río Grande River for about $120 \mathrm{~km}$. in Hidalgo and 
Cameron counties of Texas and the Mexican state of Tamaulipas, beginning on the east at the Gulf of México and ending approxmately at the level of Mission, Texas on the west. Nowhere is this Valley much more than 25 or $30 \mathrm{~km}$. wide either north or south of the river. It constitutes an island of fertile soil, relatively high humidity, and comparatively lush vegetation surrounded landward on all sides by desert scrub.

Because of its latitude ( 26 degrees N.) and proximity to the Gulf, the Valley experiences an extremely mild temperature regimen. The average yearly maximum at Brownsville is 28 degrees $\mathrm{C}$. and the minimum 18.3 degrees C. Summer highs rarely go above 40 degrees C. and the average daily range for July at Brownsville is 33.6 degrees $C$. to 24.2 degrees $C$. On the other hand, most winters have only two or three frosts during which the temperature normally does not fall below -3 to -4 degrees C., although the record low for Brownsville is -11 degrees C. (registered in February 1899). The average daily range for January at Brownsville is 21.4 degrees $C$. to 11.2 degrees $\mathrm{C}$. and such temperatures occur quite consistently throughout the Valley in winter, although from November to March warm periods frequently are interrupted by cold fronts that bring 4-10 day stretches of cloudy weather when the temperature stays between about 4 and 10 degrees $C$.

Precipitation in the Valley is rather scant, averaging $669 \mathrm{~mm}$. per year at Brownsville. It occurs in winter as protracted fine drizzle, in spring, summer, and fall as occasional thunderstorms, and sometimes in late summer and early fall as torrential inundations that accompany inland-moving hurricanes. September, with an average of $124.8 \mathrm{~mm}$. is the wettest month while March, with $26 \mathrm{~mm}$., is the driest. Although long-term figures suggest fairly even rainfall distribution, there is actually great variation from month to month and from year to year. Protracted droughts are common but some years may have more than $1000 \mathrm{~mm}$. of rain.

Vegetation of the Valley ranges from desert scrub to humid subtropical woodlands best developed along the Río Grande and in the vicinity of water holes. The south Texas flora resembles that which grows in many other semi-arid environments from México to Argentina. Some of the more conspicuous angiosperm genera are Acacia, Baccharis, Bumelia, Celtis, Cercidium, Condalia, Erythrina, Opuntia, Parkinsonia, Prosopis, Salix, Tillandsia, and Xanthoxylum. This same element occurs also in the ecologically sim- 
ilar Argentine Chaco at the austral extreme of the Neotropics.

Almost all my fieldwork on Valley mesostenines was done in the 500 acre Bentsen Park near Mission and the 20 acre Valley Botanical Garden at McAllen. Otherwise, except for the Santa Ana National Wildlife Refuge near Alamo, most natural vegetation has been extirpated from the Valley and replaced by citrus groves, truck farms, sugar-cane fields and other agricultural systems.

The Valley Botanical Garden is about $16 \mathrm{~km}$. from the Río Grande and thus lacks gallery forest and other really humid associations but offers a sample of scrub communities and moderately humid woods. Here the most abundant or conspicuous larger plants are: Acacia greggii (rare), A. farnesiana (common), Baccharis sp. (common), Bumelia celastrina (rare), Celtis lindheimeri (common), C. pallida (common), Cercidium floridum (rare), Condalia obovata (common), C. obtusifolia (common), Ehretia anacua (common), Forestiera texana (rare), Karwinskia humboldtiana (common), Leucaena pulverulenta (scarce), Morus rubra (rare), Opuntia sp. (common), Parkinsonia aculeata (common), Phaulothamnus spinescens (rare), Pithecellobium flexicaule (rare), Porlieria angustifolia (rare), Prosopis juliflora (common), Sabal texana (rare), Salix nigra (common), Serjania sp. (common), and Xanthoxylum fagara (scarce). Within its 20 acres, the Botanical Garden contains several more or less distinct associations. Dry areas are dominated by Prosopis juliflora and Opuntia sp. with Condalia obtusifolia and Parkinsonia aculeata often common also. Moderately dry habitats have at least some of the foregoing species along with Condalia obovata, Celtis pallida, Baccharis sp., and Bumelia celastrina. Moderately humid sites usually are dominated by Celtis lindheimeri in the tree stratum, C. pallida in the shrub layer, and by Serjania vines at ground level. They also may contain the small tree Ehretia anacua, the large shrub Xanthoxylum fagara, and the small shrub Karwinskia humboldtiana. The large trees Leucaena pulverulenta and Salix nigra also occur in the Garden but only near ponds and irrigation canals. Finally, some abandoned farmlands near the Garden support open Acacia farnesiana woods with a monotonous undergrowth of tall grasses.

The Bentsen Park is much larger and floristically more varied than the Botanical Garden. Only Sabal texana occurs in the Garden but not at Bentsen, while Amyris texana (common), Fraxinus berlandieriana (common), Mimosa berlandieriana (moderately com- 
mon), Sapindus drummondii (scarce), Tillandsia usneoides (common), and Ulmus crassifolia (common) have been found exclusively in the State Park. In addition to all plant associations described for the Botanical Garden, Bentsen Park supports distinctive gallery forest and water hole communities. Lush woods along the Río Grande contain Salix nigra, Fraxinus berlandieriana, Celtis lindheimeri, Mimosa belandieriana, Acacia farnesiana and a profligate ground cover of Serjania vines. Even more luxuriant is the flora near a permanent water hole, which includes huge examples of Fraxinus, Ulmus, Leucaena, and Ehretia, some Pithecellobium and Sapindus, numerous Xanthoxylum, some Mimosa, abundant Amyris, and an impressive epiphyton of Tillandsia usneoides on many larger trees. Other dark, damp zones in Bentsen Park are dominated by Pithecellobium flexicaule.

Climatically and floristically, the Valley thus emerges as decidedly subtropical and the same is true for most of its fauna, from ichneumonid wasps and diurnal Lepidoptera to reptiles and birds. Indeed, south Texas harbors the richest Neotropic biota of any part of the United States.

\section{THE TRIBE MESOSTENINI}

Mesostenines are one of the largest groups in the Family Ichneumonidae and inhabit all continents, having radiated massively in both tropical and temperate regions. They parasitize the pupae of many Lepidoptera as well as of some Coleoptera, Neuroptera, Diptera, and certain Hymenoptera. Most species are taxonomically catholic in host selection, each one being attracted to diverse kinds of pupae in a restricted spatial niche (leaf rolls, ground litter, stems, tunnels in tree trunks, etc.) rather than choosing victims from among one particular genus or even family of insects.

Like most ichneumonids, mesostenines prefer humid forest habitats, so that in the New World they are best represented in the North American Temperate Deciduous Forest and again in various kinds of Latin American subtropical and tropical wet forests. The comparatively dry Lower Río Grande Valley thus has a rather depauperate mesostenine fauna, whose relations are principally but not exclusively Neotropic.

Listed below together with relevant ecological, zoogeographic and taxonomic data are the 18 genera and 35 species of Mesostenini so far recorded from the Lower Río Grande Valley. 


\section{Gambrus bituminosus Cushman}

SPECIMENS EXAMINED: 1 female, Bentsen Park, 31 XII '76.

HABITAT: Weeds in sandy area at edge of field not far from Río Grande.

DiSTRIBUTION: Mass., N.Y., N.J., Ill., Minn., Ga., La., Cal., new for Texas.

PHAENOLOGY: Summer in north, winter in south.

\section{Gambrus ultimus (Cresson)}

SPECIMENS EXAMINED: 6 females, 2 males: BENTSEN PARK (Net: 2 females, 13 I '76; 1 female, 19 I '76; 1 female, 29 XII '76; Malaise: 1 male, $16 \mathrm{X}$ '76); BOTANICAL GARDEN (Net: 1 female, 12-21 I '76; 1 female, 17-24 III '74; 1 male, 18 III '74).

HABITAT: Serjania vine tangles under shade of Celtis lindheimeri and other large trees.

DISTRIBUTION: Continental U.S.

PHAENOLOGY: Flies in Valley from October to March with peak in January (4 of 8 collections). Active in north from April to October.

\section{Trychosis subgracilis (Cresson)}

SPECIMENS EXAMINED: 1 female, 2 males: BENTSEN PARK (Net: 1 female, 23 I '76; Malaise: 2 males, 15-30 IV '76).

HABITAT: Serjania vines in gallery woods beneath Celtis lindheimeri and Salix nigra; entered trap beneath Pithecellobium flexicaule.

DISTRIBUTION: Eastern U.S.; first record for Valley.

PHAENOLOGY: January to April in Valley; April to August in northern states.

\section{Trachysphyrus mesorufus (Cushman)}

(Fig. 6)

FEMALE: Color: scape black with a broad, nearly percurrent white bar below and brown on dorsal rim; pedicel black; flagellum black with a ventrally incomplete white band on segments 5-11; head and mesosoma black with white markings as follows: basal $2 / 3$ of the otherwise somewhat brownish mandibles; blotch covering most of clypeus; most of face except for a large area be- 
tween and below antennal sockets and a pair of submedian blotches above clypeus that are narrowly confluent mesad and which connect laterally with a large black area in anterior $1 / 4$ of malar space; very broad orbital ring interrupted only in malar space and ventroposteriorly much expanded and almost reaching hypostomal carina; blotch on apical $1 / 2$ of propleuron; very broad anterior margin of pronotum; very broad humeral margin of pronotum; pair of longitudinal blotches on about median 3/4 of mesoscutum in position of notauli; scutellum; most of postscutellum; tegula; axillary sclerites; subalarum; large anterio-median blotch on mesepisternum just behind prepectal carina; broad stripe in anterior $2 / 3$ of sternaulus; large blotch in lower hind corner of mesepisternum; mesepimeron pure white on dorsal $1 / 4$ and more brownish ventrad; most of dorsal metapleuron; large, dorso-posterior blotch on apical $1 / 2$ of lower metapleuron; and a pair of very broad blotches occupying all but median $1 / 3$ of hind face of propodeum from cristae to apical margin; first gastric tergite red with a broad white band covering apical $1 / 2$ of postpetiole; second tergite black with reddish staining baso-laterally and a broad white subapical band; and following tergites black with broad white apical bands; fore and mid legs ferruginous with tarsus duller and fifth tarsomere dusky, trochanter white with brownish above, and coxa white with a small reddish spot above near apex and more broadly marked with dark red to blackish below; hind leg with coxa red except for a small white blotch above at base, trochanter and trochantellus red, femur more ferruginous, tibia dull ferruginous with a slight dusky tinge on base and blackish on about apical 1/10, first tarsomere brownish black with white briefly throughout on apex and whitish below on apical $1 / 2$, second tarsomere white, third white with a dusky area above subapically, fourth black with a little whitish on base and fifth black; wings hyaline.

Structurally, mesorufus much resembles the Floridian T. weemsi (Porter, 1974, p. 331-335), from which it may be distinguished by most of the characters listed below:

Length of fore wing: $6.1 \mathrm{~mm}$. Pronotum: dorsal margin moderately swollen. Mesoscutum: notauli very weak but traceable about $2 / 3$ the length of mesoscutum. Mesopleuron: speculum swollen, smooth and shining with only a few large punctures peripherally; surface otherwise almost uniformly with strong, reticulate wrink- 
ling which obscures its punctures. Wing venation: radial cell 3.3 as long as wide; second abscissa of radius 0.7 as long as first intercubitus; disco-cubitus broadly angled with a long and conspicuous ramellus at angulation; upper part of nervellus 3.5 as long as lower. First gastric tergite: post-petiole 1.7 as wide apically as long from spiracle to apex. Second tergite: a little duller and more densely punctate than in weemsi. Ovipositor: sheathed portion 0.34 as long as fore wing; nodus distinct, with a very shallow and broad notch; dorsal valve on tip with a gradual, straight taper between notch and apex; tip 0.17 as high at notch as long from notch to apex.

MALE: Unknown.

SPECIMENS EXAMINED: 1 female, Botanical Garden, 2 April 1975.

DISCUSSION: As noted above, mesorufus closely resembles the Floridian $T$. weemsi except in color pattern and in some subtle structural characters, whose real value only will be established when more specimens of these elusive ichneumonids are obtained. Townes (1962, p. 256-269) considers all North American representatives of this group as subspecies of $T$. planosae. In view of their allopatry and marked differences, however, I prefer to regard them as species, pending proof of intergradation.

The Texas specimen was swept from a thorny bush (probably Celtis pallida) in a dry area of the Botanical Garden dominated by Prosopis juliflora with Condalia obovata and Celtis pallida in the shrub stratum.

The above described female is the third known specimen of mesorufus and the first from the United States. Otherwise, this species inhabits México whence it is recorded by Cushman (1930, p. 2) from Cuernavaca in Morelos state and by Townes (1962, p. 259) from " $40 \mathrm{~km}$. southwest of Puebla" in Puebla state.

\section{Joppidium brochum Townes}

SPECIMENS EXAMINED: 1 female, Botanical Garden, 5 I '76.

HABITAT: Herbaceous undergrowth on shady side of fence row with Celtis pallida, C. lindheimeri, Ehretia anacua and other trees.

DISTRIBUTION: Ky., N.C., Ga., to Okla. and Tex. and into México at least as far as Veracruz and México City.

PHAENOLOGY: Valley record for January; otherwise flies mostly in May and June. 


\section{Joppidium rubriceps Cresson}

SPECIMENS EXAMINED: 1 female, Botanical Garden, 1 IV ' 75.

HABITAT: Herbs, grasses, and pink-flowered verbenas in bright sun.

DISTRIBUTION: N. J. to south Texas.

PHAENOLOGY: Flies from mid March to early November, appearing first and disappearing latest in southern parts of its range.

\section{Lanugo picta Townes}

SPECIMENS EXAMINED: 13 females, 24 males: BOTANICAL GARDEN (Net: 4 females, 8 males, 1-15 I '75; 4 females, 8 males, 16-26 I '75; 1 female, 4 IV '75; 1 female, 1 male, 20-31 XII '73; 1 female, 5 males, 24-30 XII '74; Malaise: 1 female, III '74; 1 female, 2 males, XII '74).

HABITAT: Open and semi-shaded areas; old fields, hedge rows, woods edges; tall grass at edge of thicket dominated by Celtis lindheimeri and C. pallida; a few specimens in Celtis thicket.

DISTRIBUTION: South Texas to northern Arizona and as far south in México as Chiapas.

PHAENOLOGY: Invernal, Valley records include 3 females and 8 males for December, 8 females and 16 males for January, $1 \mathrm{fe}-$ male for March and 1 female for April. Flies all summer in mountainous parts of west Texas, Arizona and México.

Varies in abundance from year to year: 3 specimens in ' $73-' 74$, 34 in '74-'75, none in '75-'76 or so far in '76-'77.

\section{Compsocryptus texensis Townes}

SPECIMENS EXAMINED: 26 females, 6 males: BENTSEN PARK (Net: 1 male, 12-20 III '77; 2 females, 29-30 XII '76); BOTANICAL GARDEN (Net: 6 females, 5-26 I '75; 2 females, 3 males, 28-30 III '75; 5 females, 1 male, 2-5 IV '75; 1 male, 16-30 V '74; 1 female, 19 XII '76; 8 females, 20-28 XII '74; 2 females, 28-30 XII '73).

HABITAT: Open, dry areas; fields, hedge rows; short grass and low herbs of incipient secondary succession; herbage of poorly tended orange groves; lawns.

DISTRIBUTION: Ka. to Okla. and Tex. south into N. León and Tamaulipas of México. 
PHAENOLOGY: Flies from December to May with peak between December and April (13 females in December, 6 males in January, 2 females and 4 males in March, 5 females and 1 male in April, and 1 male in May).

Varies in abundance from year to year: 3 specimens in '73-'74, 25 in '74-'75, none in '75-'76, and 4 so far in '76-'77.

\section{Genus Cryptanura}

The Valley has three Cryptanura, of which one is new and one is here recorded for the first time from the United States.

\section{KEY TO THE U. S. CRYPTANURA \\ (Females only)}

1. Second gastric tergite mostly mat; clypeus more or less strongly convex in profile; humeral margin of pronotum not conically produced anteriorly, but often with a carinate elevation above end of epomia; sublateral white stripe of propodeum strongly narrowed basad of crista $\ldots \ldots \ldots \ldots \ldots \ldots \ldots \ldots .2$

Second tergite polished; clypeus nasute; humeral margin of pronotum anteriorly with a prominent subconical to conical expansion; sublateral white stripe of propodeum not narrowed basad of crista ........................

2. Epomia not reaching humeral margin of pronotum, the humeral margin not carinate or tuberculate anteriorly; second gastric tergite with a medio-basal white spot ................ .................... Septentrionalis Cushman

Epomia forms a carinate elevation on humeral margin of pronotum anteriorly; second tergite at most narrowly tinged with whitish medio-basally $\ldots \ldots \ldots \ldots \ldots \ldots \ldots \ldots \ldots$

3. Hind coxa white with conspicuous black markings; femora yellowish white with a broad, percurrent dorsal black band; lower metapleuron with coarse oblique wrinkling that becomes irregular only on about dorsal $1 / 4$ and with at most obscure intercalated punctures; propodeal dorsum behind basal trans-carina coarsely and irregularly wrinkled and puncto-reticulate but without discrete punctures.......... .................... 11. C. lamentaria (Cameron). 
Hind coxa mostly fulvous with whitish above; femora uniformly pale fulvous; lower metapleuron coarsely and densely punctate to puncto-reticulate with numerous discrete punctures dorso-anteriad; propodeal dorsum behind basal trans-carina with abundant, mostly discrete coarse punctures, grading into puncto-reticulation only latero-apicad near cristae ........ ..................... banchiformis (Megerle).

4. Many segments in apical $1 / 3$ of flagellum up to 1.4 as wide as long; first flagellomere 5.1 as long as deep at apex; malar space 0.88 as long as basal width of mandible; frontal horns on a high common base; mesoscutum with abundant large punctures but with no wrinkling along notauli, except apicad, or on outer margins of lateral lobes; mesoscutum with a large, subcircular median white spot ................ ..................... 9. C. compacta (Cresson).

Segments in apical $1 / 3$ of flagellum averaging about as wide as long; first flagellomere 7.9 as long as deep at apex; malar space 0.46 as long as basal width of mandible; frontal horns on a very low common base, long and sharp; mesoscutum with moderately numerous medium sized punctures that become sparser mesad on lobes and with extensive transverse wrinkling all along notauli and on outer margins of lateral lobes; mesoscutum without a median white spot ......... 10. C. vallis n. sp.

\section{Cryptanura compacta (Cresson)}

SPECIMENS EXAMINED: 1 female, Bentsen Park, 14 III '77.

HABITAT: Clearing with Serjania vines and tall grass on bank of Río Grande in Salix nigra-Celtis lindheimeri woods.

DISTRIBUTION: Southern Texas to Honduras.

PHAENOLOGY: Townes (1962, p. 429-30) records a female of compacta from "Cameron County, Texas, 3 August 1928".

\section{Cryptanura vallis n. sp.}

(Fig. 8)

Holotype: female, USA (Texas: Hidalgo County, Bentsen Río Grande Valley State Park, 27 XII '76, C. C. Porter). (Townes). 
FEMALE: Color: antenna black with white annulus on flagellomeres 5-12; palpi whitish; mandible white with black on apical 1/3 and narrowly on dorsal and ventral margins except near base; head white with black as follows: broad, irregular mark extending from a little above anterior tentorial pit ventrad to mandibular condyle; face for a short distance below and between antennal sockets; lower and inner margins of antennal sockets; median half of face and vertex; occiput much more broadly; most of postocciput; about upper $1 / 4$ of temple very broadly, briefly interrupting white orbital ring; and rest of temple very narrowly along occipital carina; propleuron white with black on most of basal $1 / 4$; pronotum black with a broad white band covering most of front margin, except for lower hind corner and a short break dorso-medially, and with white broadly on the swollen humeral margins; thoracic dorsum black with white on prescutellar ridge, broad anterio-lateral margins and most of apical 1/2 of scutellum, most of postscutellum, and on hind margins of meso and metanotal axillary troughs; tegula white; mesopleuron black on most of prepectus and on most of upper 1/3 except for the white subalarum, otherwise wholly white, becoming slightly brownish ventrad, on mesepisternum and mesepimeron; mesosternum black on prepectus but otherwise slightly brownish white; most of dorsal metapleuron white; lower metapleuron white with a pale brownish tinge and briefly stained with darker brown on apex; propodeum white to brownish white with black on a broad, irregular percurrent median longitudinal band which is widest along basal trans-carina and becomes narrower rearward, especially on apical face, as well as at least narrowly blackish throughout along basal carina, blackish around spiracle, and with pale brown staining on much of lateral face between spiracle and crista; first gastric tergite yellowish white with dark brown above on much of apical half of petiole and on most of basal 2/3 of postpetiole as well as a little brownish along ventro-lateral carina; second tergite black with yellowish white on apical $1 / 3$, on very broad lateral margins, and on entire thyridial areas, between which the ground color becomes brownish yellow basad; third tergite black with yellowish white on apical $1 / 2$ and on very broad lateral margins; fourth and fifth similar but even more broadly yellowish with some darker staining in the yellow zones; sixth and seventh yellowish with some darker staining; and eighth dark brown with apex narrowly yellow; fore leg with coxa white, trochanter whitish with 

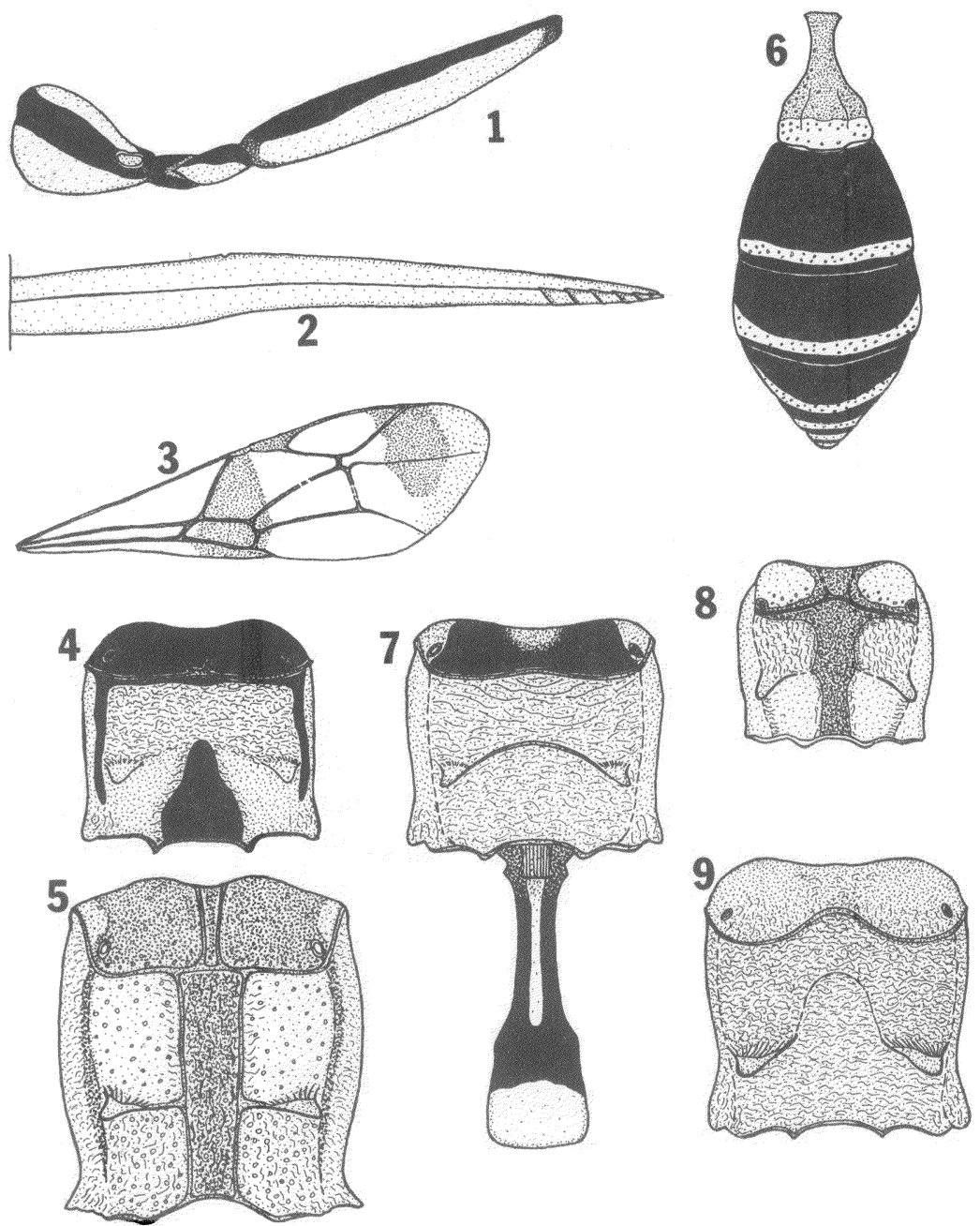

Fig. 1. Cryptanura lamentaria, female. Bentsen Park. Side view of hind coxa, trochanters, and femur, showing color pattern. Fig. 2. Mesostenus opuntiae, female holotype. Ovipositor tip. Fig. 3. Lymeon leucosoma, female. Valley Botanical Garden. Fore wing. Fig. 4. Diapetimorpha aspila, male holotype. Dorsal view of propodeum. Fig. 5. Bicristella taxana, female holotype. Dorsal view of propodeum. Fig. 6. Trachysphyrus mesorufus, female. Valley Botanical Garden. Dorsal view of gaster, showing color pattern. Fig. 7. Diapetimorpha pareia, male holotype. Dorsal view of propodeum and first gastric segment. Fig. 8. Cryptanura vallis, female holotype. Dorsal view of propodeum. Fig. 9. Diapetimorpha sphenos, female paratype. Dorsal view of propodeum. 
a brown blotch on basal $2 / 3$ above, trochantellus whitish with some brown staining, femur yellowish white below and mostly brownish above, tibia yellowish white, and tarsus dull yellowish with slight dusky staining toward apex on first segment, more broadly dusky on second and third segments, and blackish almost throughout on fourth and fifth; mid leg similar to fore leg but coxa more dully white with some faint dusky staining, trochanter and trochantellus more broadly brown above, and tarsus mostly dusky to black with yellowish only near base of segments $1-3$; hind leg with coxa dull white with a broad but diffuse, nearly percurrent, moderately pale brownish dorsal stripe and with paler brownish staining within and below; trochanter yellowish white with dark brown staining dorso-anteriorly and tinged with paler brown behind; trochantellus similar to trochanter but with darker and more extensive brown areas in front and behind; femur dull brownish yellow, becoming darker brown above and brighter yellow behind; tibia yellow with a little dusky on base; and tarsus yellow with dusky only on apical $1 / 2$ of fifth segment; wings hyaline, stigma yellowish with dark brown on broad peripheries.

Length of fore wing: $8.7 \mathrm{~mm}$. Flagellum: scarcely flattened below on apical 1/3, segments between white annulus and apex averaging as wide as long; first segment 7.9 as long as deep at apex. Temple: 0.3 as long as eye at upper $1 / 3$; very strongly and directly receding. Front: horns on a very low common base, large and sharply conical; surface practically without wrinkles between level of horns and anterior ocellus. Clypeus: nasute; apical margin truncate. Pronotum: epomia sharp in scrobe but ending above in a large tubercle, so that the otherwise gently swollen dorsal margin of pronotum has a moderately prominent subconical projection at this point. Mesoscutum: shining with numerous medium sized punctures that become sparser centrad on lobes and rather broadly, more or less transversely wrinkled interiorly and exteriorly along notauli and on outer margins of lateral lobes as well as with an area of coarse, irregular wrinkling between notauli toward their terminus; notauli moderately impressed, reaching about $4 / 5$ the length of mesoscutum. Scutellum: weakly convex. Mesopleuron: prepectus with a very short ridge opposite lower hind corner of pronotum; surface between prepectal carina and speculum mostly with strong, nearly regular longitudinal wrinkling which becomes weaker, and mingled with large, obscure punctures, on lower half, 
where there are also some smooth areas. Lower metapleuron: with uniform, coarsely reticulate wrinkling; juxta-coxal carina not defined. Front tibia: moderately inflated. Hind trochantellus: 0.57 as long as its trochanter in dorsal view. Third hind tarsomere: ventrally with about 8-9 strong spines (in addition to the apical group) which are not arranged in regular longitudinal rows. Propodeum: spiracle 1.5 as long as wide; cristae large and strongly projecting short ligulate, about 1.1 as long as wide at base, apical carina weakly defined and gently arched forward between them; dorsal face behind basal trans-carina with rather coarse, irregular but not much reticulate wrinkling; the apical face centrally with strong longitudinal wrinkling, becoming smooth sublaterally and then transversely wrinkled laterad. First gastric tergite: postpetiole 1.4 as wide at apex as long from spiracle to apex; gently arched in profile. Second gastric tergite: smooth and highly polished with a few tiny, very sparse punctures. Ovipositor: sheathed portion 0.43 as long as fore wing; tip 0.20 as high at nodus as long from nodus to apex, weakly sagittate with a direct taper between nodus and apex.

MALE: Unknown.

TYPE: In collection of Dr. Henry K. Townes, 5950 Warren Rd., Ann Arbor, Michigan, 48105.

RELATIONSHIPS: The polished second gastric tergite, nasute clypeus, and rather strong subconic projection anteriorly on the humeral margin of the pronotum suggest affinity with C. compacta, to which vallis runs in Townes' key to the North American Cryptanura (1962, p. 427). However, compacta differs from vallis in many chromatic and structural features of which those not already mentioned in my foregoing key are summarized below:

Mesopleuron black on lower $2 / 3$ except for a broad, oblique white area extending from prepectal carina to lower hind corner but not invading speculum or approaching mesopleural suture except far below; propodeum black with a very broad white stripe on each side reaching rearward from basal trans-carina across crista to hind margin; fore and mid femora broadly black above; hind coxa pure white with an almost percurrent broad black stripe dorsally and with other black markings; hind femur black with yellow anteriorly and posteriorly; dorsal margin of pronotum very strongly swollen and produced anteriorly into an exceptionally prominent broadly conical projection; prepectus opposite lower 
hind corner of pronotum with a strong ridge that extends ventrad about $3 / 4$ the distance to prepectal carina; mesopleuron behind prepectal carina with coarser and more oblique wrinkling than in vallis; front tibia a little more strongly inflated than in vallis; propodeal spiracle 2.0 as long as wide; propodeal cristae a little more narrowly ligulate than in vallis, 1.4 as long as wide at base; apical trans-carina completely absent between cristae; dorsal face of propodeum behind trans-carina with more regularly reticulate wrinkling than in vallis; apical face of propodeum with coarse reticulate wrinkling that becomes transversely biased laterad; first gastric tergite more strongly arched in profile than in vallis; postpetiole 1.6 as wide at apex as long from spiracle to apex.

FIELD NOTES: Swept from Serjania vines near Río Grande in shade of Celtis lindheimeri, Salix nigra, Fraxinus berlandieriana and other trees.

SPECIFIC NAME: Vallis is the genitive of the Latin noun valles or "valley".

\section{Cryptanura lamentaria (Cameron)}

(Fig. 1)

FEMALE: Color: antenna black with a broad white stripe below on scape and a white annulus on flagellomeres 6-11; palpi white with apical segment of each blackish; mandible mostly black with a large white blotch on base; clypeus white with black on median $2 / 3$ and pale brown on lateral 1/3 of apical margin as well as broadly black on lateral and dorso-lateral margins around and mesad of anterior tentorial pits; white on most of face, cheek, and a broad orbital ring which is narrowed and briefly interrupted on upper 1/4 of temple; head otherwise with black on median half of front and vertex and more broadly on occiput and postocciput as well as increasingly narrowly black ventrad along occipital carina to about dorsal 1/2 of temple; mesosoma black with profuse white markings as follows: about apical 3/4 of propleuron; broad front margin of pronotum, ending about $4 / 5$ the distance ventrad to lower hind corner and also enclosing a pair of small, dorso-lateral black spots; all but about median 1/6 of dorsal margin of pronotum very broadly; large median spot on mesoscutum between apices of notauli; prescutellar ridge; most of scutellum except for an anterio-median black spot; most of post-scutellum; hind rims of 
meso and metanotal axillary troughs; tegula; subalarum; very broad oblique band across mesopleuron from mid-height of front margin to lower hind corner; about upper 1/3 of mesepimeron; a pair of very large blotches covering much of mesosternum on each side of median groove and confluent posterio-dorsad with white mesopleural band; most of dorsal metapleuron; about dorso-posterior $3 / 4$ of lower metapleuron; and a pair of broad propodeal stripes which extend dorsad from hind margin to include cristae and then reach forward, a little more narrowly, almost to basal trans-carina; first gastric tergite black with yellowish white dorsally on much of petiole and on about apical $1 / 2$ of postpetiole as well as laterally toward apex of petiole and on most of postpetiole; second tergite black with a brown tinged yellowish white band on base, abruptly widened sublaterally to cover thyridia, as well as broadly yellowish white laterally and on apical $1 / 3$; third and fourth tergites black with very broad apical and lateral yellowish white bands; fifth and sixth mostly yellowish white grading into black dorsad; seventh similar to preceding but more broadly black dorsally; eighth and ninth black with yellowish white laterally and on apical rims; fore and mid coxae white with black on most of apical $1 / 2$ posteriorly; hind coxa yellowish white with a broad, percurrent anterio-dorsal black band and a similar but premedially interrupted posteriodorsal band as well as blackish on extreme base ventrally; trochanters and trochantelli whitish with considerable black above; femora yellowish white with a broad, percurrent dorsal black band; tibiae yellow with some dusky staining posterio-basally on front and mid tibiae and a little more broadly blackish on base of hind tibia; fore and mid tarsi with first segment yellow with a little dusky staining apicad and succeeding segments blackish except narrowly yellow on base of second; hind tarsus with segments 1-4 yellow and 5 mostly black except grading into brownish on base; and wings hyaline with stigma black.

Length of fore wing: $10.7 \mathrm{~mm}$. Flagellum: definitely flattened below on apical $1 / 3$, its widest segments 1.5 as wide as long, the first segment 5.7 as long as deep at apex. Malar space: 0.71 as long as basal width of mandible. Temple: 0.4 as long as eye at upper 1/3; strongly and directly receding. Front: horns stout and broad, not on a common base; strongly wrinkled between level of horns and anterior ocellus. Clypeus: strongly and a little asymmetrically convex in profile; apical margin slightly convex. Pro- 
notum: epomia strong in scrobe and reaching far dorsad onto the moderately swollen humeral margin of pronotum, where it forms a carinate elevation. Mesoscutum: shining with abundant coarse, medium-sized punctures which are mostly subadjacent to a little sparser; notauli sharp and narrow, reaching about $2 / 3$ the length of mesoscutum. Scutellum: gently convex. Mesopleuron: prepectus opposite lower hind corner of pronotum with a long ridge that extends $2 / 3$ or more the distance ventrad to prepectal carina; surface between prepectal carina and speculum with strong oblique wrinkling that on lower $1 / 2$ becomes only gradually a little weaker and mingled with large but mostly obscure punctures; mesopleural suture grossly foveolate on lower $1 / 2$. Lower metapleuron: with coarse oblique wrinkling that becomes more irregular dorsad and has only obscure intercalated punctures; juxta-coxal carina traceable for about basal 0.5 of metapleuron. Front tibia: moderately inflated. Hind trochantellus: 0.36 as long as trochanter in dorsal view. Third hind tarsomere: in addition to apical spines with four longitudinal rows of strong spines numbering about 15 in all. Propodeum: spiracle 1.9 as long as wide; cristae strongly projecting ligulate, about 2.0 as long as wide at base, the apical trans-carina absent between them; dorsal face behind basal trans-carina with strong irregular wrinkling and puncto-reticulation but without discrete punctures; apical face almost uniformly with strong and quite regular transverse wrinkling. First gastric tergite: postpetiole 1.5 as wide at apex as long from spiracle to apex; in profile pyramidally elevated above spiracle. Second gastric tergite: mostly mat with fine micro-reticulation and on about basal $2 / 3$ with numerous shallow, medium-sized punctures separated in general by about 1.0-2.0 their diameters. Ovipositor: sheathed portion 0.46 as long as fore wing; tip 0.2 as high at nodus as long from nodus to apex, its profile between nodus and apex only slightly convex.

MALE: Unknown.

SPECIMENS EXAMINED: 2 females, USA (Texas: Hidalgo County, Bentsen Río Grande Valley State Park, 29 XII '76, C. C. Porter); PANAMÁ (Chiriquí: Valley of the Clouds, 17 III '60, K. W. Brown). (Porter, Townes).

DISCUSSION: This is the first record of lamentaria for the United States. The species has been cited previously only from Costa Rica, Guatemala, and Panamá.

A homotype from Panamá, loaned by H. K. Townes, is un- 
doubtedly conspecific with the Texas specimen, differing only as follows:

No white on scape; apical segments of palpi only slightly dusky; white band on anterior margin of pronotum briefly interrupted medially; all of lower metapleuron white; gastric tergites 4-9 more broadly white; posterio-dorsal black band of hind coxa percurrent; first flagellomere 6.3 as long as deep at apex; malar space 0.83 as long as basal width of mandible; ridge on lower prepectus extending about $2 / 3$ the distance ventrad to prepectal carina; hind trochantellus 0.47 as long as its trochanter in dorsal view; punctures of second gastric tergite sparser, mostly separated by more than 2.0 their diameters.

Among its relatives, lamentaria most resembles C. banchiformis of the eastern United States and the two nearly replace one another geographically since banchiformis ranges down to San Antonio, Texas within less than $500 \mathrm{~km}$. of the Valley. Lamentaria differs from banchiformis mainly in its black and white (instead of mostly fulvous) femora and in having the lower metapleuron and propodeal dorsum strongly wrinkled but with at most obscure intercalated punctures (instead of with numerous discrete punctures). The two species probably stem from a common ancestor which, during warmer and wetter Tertiary times, ranged uniformly from México up along the Gulf arc into eastern United States but then was fragmented by Pleistocene glacial maxima into southeastern (Florida) and southwestern (México) isolates, which have practically reestablished contact during the present moderately warm interglacial.

The unique Texas female was netted as it flew about a tangle of Serjania vines in gallery woods along the Río Grande. This is the same habitat and same general area where $C$. compacta and $C$. vallis also were collected.

\section{Genus Mesostenus}

\section{Mesostenus gracilis Cresson}

SPECIMENS EXAMINED: 6 females, BENTSEN PARK (Malaise: 1 female, 1-15 V'76); BOTANICAL GARDEN (Net: 1 female, 16-30 V' 74 ; Malaise: 4 females, III '74).

HABITAT: Herbaceous undergrowth in Celtis lindheimeri-C. pallida woods.

DISTRIBUTION: U.S. and northern México. 
PHAENOLOGY: March to May in Valley; flies from March to November elsewhere in southern part of its range and from late May to mid-October farther north.

\section{Mesostenus opuntiae n. sp.}

(Fig. 2)

Holotype: female, USA (Texas: Hidalgo County, Valley Botanical Garden at McAllen, 10 I '76, C. C. Porter). (Townes).

FEMALE: Color: scape black with a little dull brown below; pedicel black with dull brown on apex; flagellum black with a little pale brown on base of first segment and a ventrally interrupted white band on segments 6-11; palpi brownish white; mandible white on basal half with apical half grading through pale brown into black on teeth; head mostly white on clypeus, cheek, face, and on a broad, uninterrupted orbital band, which progressively widens rearward and below to cover much of temple, as well as with pale brownish on mandibular condyles, hypostomal carina, medio-dorsal margin of clypeus, slightly on apical face and apical margin of clypeus, and on antennal sockets, and with black broadly and irregularly along lateral and dorso-lateral margin of clypeus, irregularly around antennal sockets below, on about median half of front and vertex, more broadly on occiput and post-occiput, and then increasingly more narrowly ventrad on temple along occipital carina to about its lower 1/5; pronotum black basally with fulvous on apical half that grades into dull white on apical margin; pronotum black with a broad white band on most of front margin and on all but about median $1 / 5$ of dorsal margin; mesoscutum black with a median white blotch located between apices of notauli and with white on pre-scutellar ridge; scutellum black, broadly margined with white laterally and behind; postscutellum mostly white; meso and metanotal axillary troughs black with hind rims narrowly whitish; mesosoma otherwise fulvous with white on tegula, subalarum, broadly on about upper 4/5 of front margin of mesepisternum, toward dorsum of mesepimeron, dully in lower hind corner of mesepisternum, and dully on apex of lower metapleuron, as well as with black above, below and behind subalarum, on most of prepectus, on most of apex of metasternum in front of mid coxae, in most of groove at base of propodeum, irregularly ventrad on front margin of lower metapleuron, rather irregularly on submeta- 
pleural carina and on most of metasternum; gaster fulvous with some faint and diffuse dusky staining; legs fulvous with tibiae and tarsi duller and fifth tarsomeres dusky, front coxa extensively white above and in front with a large dark brown dorsal blotch enclosed by the white, front trochanter white tinged dorso-anteriorly and with slight dusky staining above; mid coxa with a large white blotch on basal half anterio-dorsally, mid trochanter brownish stained above; and with a little dusky on apex of hind trochantellus; wings hyaline with stigma pale brown.

Length of fore wing: $6.3 \mathrm{~mm}$. First flagellomere: 5.0 as long as deep at apex. Clypeus: small, in profile rather strongly and a little asymmetrically convex, its apical margin slightly convex. Malar space: 0.85 as long as basal width of mandible. Temple: at its upper $1 / 3$ about 0.34 as long as eye in lateral view; strongly receding and gently convex. Mesoscutum: smooth and shining with abundant, moderately small, sharp punctures (coarser and denser in thoracicus). Mesopleuron: prepectal carina sharp to about lower 0.2 of hind margin of pronotum and then becoming obsolete in a vertically elliptic, slightly raised white callus. Wing venation: areolet 1.3 as wide as high at apex; nervulus interstitial. Hind trochantellus: 0.20 as long as hind trochanter in dorsal view. Propodeum: elongate and rather strongly sloping rearward with little discontinuity between basal and apical face, apical face 0.7 as long as basal; apical trans-carina absent medially, laterally forming very low, broad, weakly oblique subcrescentic cristae; surface strongly and densely punctate with some intercalated wrinkling, especially rearward and a little more finely and sparsely punctate basad of basal trans-carina. First gastric segment: postpetiole 0.81 as wide apically as long from spiracle to apex. Second gastric tergite: mat with very fine but well developed micro-reticulation and abundant small, shallow punctures separated mostly by a little more or a little less than their diameters. Ovipositor: sheathed portion 0.83 as long as fore wing; tip 0.7 as long from nodus to apex as deep at nodus.

MALE: Unknown.

TYPE: In collection of Henry K. Townes, 5950 Warren Rd., Ann Arbor, Michigan, 48105.

RELATIONSHIPS: This species resembles M. sicarius Townes (1962, p. 448-450), especially because of its short prepectal carina which ends dorsally in a white callus, but may be distinguished by the characters summarized in the following key: 
1. Ovipositor tip 0.7 as long from nodus to apex as deep at nodus; propodeal cristae weakly oblique; first flagellomere 5.0 as long as deep at apex; postpetiole 0.83 as wide apically as long from spiracle to apex; propodeal punctation definitely sparser basad of basal trans-carina; second gastric tergite mat with small punctures separated in general by a little more to somewhat less than their diameters ........ M. opuntiae n. sp.

Ovipositor tip 11.5 as long from nodus to apex as deep at nodus; propodeal cristae strongly oblique; first flagellomere 4.2 as long as deep at apex; postpetiole 0.95 as wide apically as long from spiracle to apex; propodeal punctation hardly sparser basad of basal trans-carina; second gastric tergite more shining with small punctures separated mostly by about 1.5 their diameters ...................... sicarius Townes.

FIELD NOTES: Netted in arid Prosopis-Opuntia association. SPECIFIC NAME: from the genitive singular of Opuntia.

\section{Mesostenus longicaudis Cresson}

SPECIMENS EXAMINED: 5 females, 7 males: BENTSEN PARK (Net: 1 female, 12-20 III '77; Malaise: 1 male, 16-31 V'76); BOTANICAL GARDEN (Net: 1 male, 12-20 III '77; 2 females, 15 III '76; 1 female, 1 IV '75; 2 males, 27 VIII '76; 1 female, 3 males, 3-9 IX '76).

HABITAT: Herbaceous growth in abandoned orange groves; amid pink verbenas on an otherwise well-cut lawn; weedy areas at edge of woods; rarely strays into deep woods; flies in full sunlight.

PHAENOLOGY: Peaks in spring and late summer. Seems absent in winter and June-July. Valley records include 4 specimens for March, 1 for April, 1 for May, 2 for August, and 4 for September. Flies from mid-spring to mid-fall in most of south but does not appear before early July in north.

DISTRIBUTION: Most of U.S. and México.

\section{Genus Bicristella}

This is the first record of Bicristella from the United States.

15. Bicristella texana $\mathrm{n} . \mathrm{sp}$.

(Fig. 5)

Holotype: female, USA (Texas: Hidalgo County, Bentsen Río Grande Valley State Park, 29 XII '76, C. C. Porter). (Townes). 
FEMALE: Color: antenna black with a white annulus on flagellomeres 5-11 and a little brownish toward apex below; maxillary palpus white with a little brownish on apical segment; labial palpus white with dusky toward apex of penultimate and on all of apical segment; mandible white with apical $1 / 4$ dark brown; head white with black or blackish markings as follows: narrow apical margin of clypeus; rather broad ventral margin of anterior $1 / 2$ of malar space; weak staining on mandibular condyle; some staining around anterior tentorial pit; narrow median line on about upper $1 / 3$ of face; antennal sockets largely; a little more than median 1/2 of front and vertex; occiput more broadly; most of post-occiput; and temple, increasingly more narrowly, ventrad along occipital carina to about its upper 0.4; propleuron white; pronotum black with front margin very broadly white, except for a narrow dorso-median interruption, and all but about apical 1/4 of humeral margin broadly white; thoracic dorsum black with white on a large callus-like area on lateral lobe of mesoscutum above tegula, on prescutellar ridges and broad lateral and very broad apical margins of scutellum, on post-scutellum, and on apical rims of meso and metanotal axillary troughs; tegula white internally grading marginally into blackish; mesosternum and mesopleuron white with weak testaceous suffusion on all but about upper $1 / 3$ of mesopleuron, as well as with black above subalarm, obliquely between apex of subalarum and dorsal margin of speculum and in subspecular depression; upper metapleuron almost wholly white; lower metapleuron white with a faint testaceous tinge; part of propodeum basad of basal transcarina black with slightly testaceous white on much of lateral $1 / 5$, except for black margining spiracle behind, as well as more narrowly white all along basal trans-carina and finely whitish on median longitudinal carinae; part of propodeum behind basal transcarina also slightly testaceous white with an almost percurrent black stripe between median longitudinal carinae and a black stripe along all of pleural carina except near apex; first gastric segment white with a large black area on apex of petiole and about basal $2 / 3$ of postpetiole, narrowly black on apex of post-petiole, and with a broad, almost percurrent black stripe ventro-laterally; second tergite black with a broad subapical white band, even more broadly white laterally, and with a transverse white blotch medially at about basal 1/5; third tergite like second but without a sub-basal white blotch; following tergites similar to third but with the subapical 
white band increasingly narrower mesad and broadly interrupted medially on sixth and following; fore leg pale testaceous with coxa white, except for a brownish streak dorso-basally, and tarsomeres 2-5 mostly dusky; mid leg similar to fore leg except for weak testaceous staining on coxa; hind leg pale testaceous with coxa grading into white near base and with a broad, percurrent, weakly contrasting pale brownish stripe on its dorsum and with tarsus yellow except for blackish on the last segment; wings hyaline with stigma whitish grading marginally into pale brown.

Length of fore wing: $7.4 \mathrm{~mm}$. Flagellum: scarcely flattened below toward apex; first segment 6.4 as long as deep at apex. Front: horn large, stout and conical, situated a little below center of front. Clypeus: bluntly nasute; apical margin convex. Malar space: 0.75 as long as basal width of mandible. Occipital carina: fine and sharp, joining the moderately raised hypostomal carina below in a weak depression at a distance above base of mandible equal to about $1 / 2$ basal width of mandible. Temple: strongly and directly receding; 0.21 as long as eye at upper 1/3. Pronotum: humeral margin strongly swollen, evenly rounded and not especially prominent at anterior end; epomia strong throughout in scrobe but not prolonged dorsad or ventrad; anterior margin bluntly angulate below middle. Mesoscutum: smooth and polished with a few sparse punctures; notauli sharply impressed and reaching about $2 / 3$ the length of mesoscutum; lateral lobe opposite tegula with a large, gently raised, nearly circular white callus which is set off internally by a longitudinal impression. Mesopleuron: subalarum swollen; prepectal carina reaches dorsad about to upper 0.5 of hind margin of pronotum; prepectus opposite lower hind corner of pronotum with a rather high ridge that extends about $1 / 3$ the distance ventrad to prepectal carina; surface shining with strong longitudinal wrinkling that becomes weaker and partially interrupted on upper $1 / 2$, where there are some scattered large punctures, as well as ventro-posteriorly, where there are more numerous large punctures. Lower metapleuron: with strong oblique wrinkling that grades anterio-dorsad into puncto-reticulation and finally becoming smooth for a short distance near front margin. Wing venation: areolet 1.6 as wide as high at apex; second recurrent a little basad of second intercubitus; nervulus slightly antefurcal; postnervulus broken at lower 0.4 . Fore tibia: moderately inflated. Hind femur: 1.6 as deep at middle as at apex. Hind tibia: inner spur 0.41 as long as basitarsus. Propo- 
deum: spiracle 1.4 as long as wide; basal trans-carina almost straight medially; apical trans-carina represented sublaterally by strong, broadly cuneate cristae but interrupted on median $1 / 3$ of propodeum; median longitudinal carinae well defined throughout and enclosing a very narrow, parallel-sided area-basalis and a broader but also long and parallel-sided combined areola and median apical area; pleural carina obsolete; surface shining, apicad of basal transcarina with more numerous very large puntures that are moderately sparse on area dentipara but which become denser and mingled with longitudinally biased to reticulate wrinkling on areola, median apical area, and latero-apical area. First gastric segment: petiole with a sharply triangular lateral expansion at base; postpetiole 0.6 as wide at apex as long from spiracle to apex. Second gastric tergite: smooth and highly polished with scattered tiny punctures emitting short, sparse setae. Succeeding tergites: with denser tiny punctures and setae which in part equal or exceed the length of their interspaces. Ovipositor: sheathed portion 0.51 as long as fore wing; tip 0.15 as high at nodus as long from nodus to apex, dorsal valve with a very long and slightly concave taper between nodus and apex.

TYPE: In collection of Henry K. Townes, 5950 Warren Rd., Ann Arbor, Michigan, 48105.

RELATIONSHIPS: Texana resembles the Mexican and Guatemalan B. humerosa (Cushman, 1931, p. 51-52, fig. 4 on p. 4) but differs in that the occipital carina reaches the hypostomal carina below (becomes obsolete below in humerosa), because the propodeum anteriad of the apical trans-carina is punctured on the area dentipara and longitudinally rugose medially (polished before the apical trans-carina in humerosa), in the well-defined, elongately rectangular areola (in humerosa the apical trans-carina is acutely angled forward medially and a single median longitudinal carina reaches forward from the vertex of the angulation to the basal trans-carina), and in having the apical margins of gastric tergites 2 and 3 narrowly black (no black on apical margins in humerosa).

From the other Mexican Bicristella, B. univittata (Cresson), texana differs because the occipital and hypostomal carinae join in a weak declivity (instead of being separated by a broad, deep depression), by its shorter temple ( 0.21 as long as eye at upper $1 / 3$ vs. 0.38 in univittata), and by its longer epomia, medially longitudinally wrinkled (instead of mostly smooth and polished) mesopleuron, 
narrow and well-defined area-basalis (broadly and poorly developed in univittata), and black and white (instead of uniformly testaceous) gaster.

B. bicarinata (Cushman) from Panamá may be separated from texana by its color (ferruginous with head black) and by many structural features (clypeus not prominent in profile, occipital carina separated by a deep groove from hypostomal carina, temple concave in dorsal view, mesopleuron finely and sparsely punctate, subalarum reduced to a carina, and propodeum sparsely punctate with its apical trans-carina forming medially an acute angle from which a single carina extends forward to the basal trans-carina).

Cameron's (1885, p. 236) original diagnosis of B. chontalensis, the only other described Middle American Bicristella, shows that his species has a short frontal horn (horn is long in texana) and that it deviates chromatically from texana in numerous aspects (mandible black at base, mesoscutum with a yellow line along outer edge of central lobe and without a white callus opposite tegula, lower metapleuron with a black mark over hind coxa, petiole black at base, and fore and mid coxae with a black line at base and a larger black spot at apex, and hind coxa marked with yellow).

The Cuban B. tricolor (Brullé) resembles texana because its occipital carina is complete ventrad to the hypostomal carina and the mesopleuron is discally striate but may be distinguished because it has two deep pits at the base of the frontal horn, the anterio-lateral margin of the pronotum sharply angulate below the middle, the scape below and apex of the frontal horn white, the mesoscutum with discal white lines that extend nearly the length of the inner margins of the lateral lobes, and the legs mostly ferruginous.

Finally, B. testacea (Taschenberg), the only other described Bicristella, ranges over most of South America and differs strikingly from the black, white and testaceous texana in being uniformly ferruginous to testaceous with only the head black.

FIELD NOTES: Swept near R. Grande from Serjania vines in Salix-Celtis-Fraxinus gallery woods.

SPECIFIC NAME: for the state of Texas.

\section{Genus Diapetimorpha}

The Valley has seven Diapetimorpha, of which three are described as new. 


\section{KEY TO THE U.S. DIAPETIMORPHA}

\section{Females \\ (Females of pareia and aspila unknown)}

1. Propodeum black with conspicuous white markings, including at least a broad band on each side that reaches from somewhat in front of crista to or nearly to hind margin ......2 Propodeum black or ferruginous to fulvous, its pale markings, if any, confined to cristae and often area immediately around cristae .................................

2. Malar space 0.50 as long as basal width of mandible; propodeal cristae low, about 0.37 as long as their basal width; propodeum basad of basal trans-carina with a pair of large white lateral blotches; gastric tergites 2-6 blackish basally with broad fulvous and whitish apical bands .............. ......................... D. picta Townes.

Malar space 0.70 as long as basal width of mandible; propodeal cristae longer, about 0.9 as long as their basal width; propodeum wholly black basad of basal trans-carina; gastric tergites 2-6 wholly fulvo-ferruginous ....... D. rufigaster Cushman

3. Pronotum and mesoscutum black, with or without white mark-

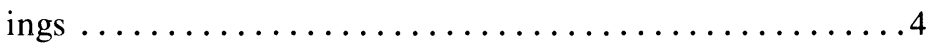

Pronotum and mesoscutum fulvous or ferruginous, with or without white markings $\ldots \ldots \ldots \ldots \ldots \ldots \ldots \ldots$

4. Malar space 0.80 as long as basal width of mandible; head and mesosoma almost uniformly black and white at most only on propodeal cristae and sometimes very slightly on scutellum; gaster wholly feruginous...... 21. D. introita (Cresson).

Malar space $0.60-0.70$ as long as basal width of mandible; head, pronotum, and mesoscutum black with white markings; mesopleuron, metapleuron and propodeum extensively fulvous to ferruginous; always a large median white blotch on gastric ter-

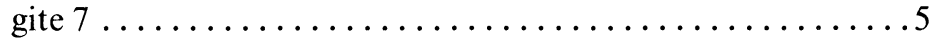

5. First flagellomere 6.6-7.1 as long as deep at apex; lower metapleuron with coarse, mostly longitudinally biased wrinkling that becomes somewhat reticulate only on dorsal $1 / 4$ or less; dorsal face of propodeum between trans-carinae with strong, more or less longitudinally biased wrinkling; propodeal cristae 
strongly projecting subligulate to ligulate, $0.7-1.2$ as long as wide at base; broad white orbital ring interrupted only at bottom of eye; humeral margin of pronotum white throughout; scutellum pure white; first gastric tergite with a white apical band (except in S. Florida populations) ............... ....................... 16. D. macula (Cameron).

First flagellomere 5.5-6.0 as long as deep at apex; lower metapleuron with strong longitudinal wrinkling that becomes reticulate on dorso-posterior half; dorsal face of propodeum between trans-carinae with strong, complexly reticulate wrinkling; propodeal cristae prominent, broadly cuneate, $0.4-0.5$ as long as wide at base; white only on frontal orbit; humeral margin of pronotum more than half black; scutellum yellowish ferruginous; no white on apex of first gastric tergite ......... ........................... D. sphenos n. sp.

6. Lower metapleuron with strong longitudinal wrinkling; whitish at least on pronotal collar and propodeal cristae ........7 Lower metapleuron either only punctate or punctate and obliquely wrinkled; no white on mesosoma $\ldots \ldots \ldots \ldots \ldots . . .6$

7. Malar space 0.80 as long as basal width of mandible; mesosoma brownish ferruginous, except for whitish pronotal collar and propodeal cristae; fourth gastric tergite dusky ............

D. brunnea Townes

Malar space $0.63-0.73$ as long as basal width of mandible; mesosoma fulvous with profuse yellowish white markings including scutellum, humeral margin of pronotum, and a pair of median stripes on mesoscutum; fourth gastric tergite fulvous. ........................ D. alabama Cushman

8. Malar space $0.65-0.75$ as long as basal width of mandible .... 22. D. acadia Cushman Malar space 1.05 as long as basal width of mandible ....... D. rugosa Townes

Males

1. Gastric tergites 2-7 black or brownish black with broad white

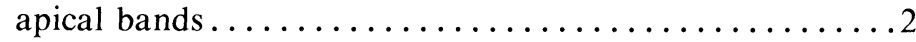

Gastric tergites 2-7 ranging from yellowish fulvous to ferruginous, sometimes with blackish basal bands but never with white apical bands ......................... 
2. Tyloides sharp longitudinal carinae on flagellomeres 11 or 12 to 19 , those of 12 or 13 to 17 or 18 extending more or less the length of their segments; mesopleuron and lower metapleuron largely with medium-sized coarse punctures that mostly are separated by less than 2.0 their diameters or sometimes in part on metapleuron and on mesopleuron in front of speculum with puncto-reticulation to more or less regular longitudinal wrinkling; mesopleuron black with white on subalarum and sometimes one or two whitish blotches on lower $1 / 4$ above sternaulus .....21. D. introita (Cresson) Tyloids often very faint and not extending nearly the length of their segments, at most flagellomeres 12 to 15 with sharp, carinate tyloids reaching $0.4-0.6$ their length; mesopleuron and lower metapleuron with small to tiny rather weak punctures separated in general by 2.0 or more their diameters and without wrinkling or puncto-reticulation, except sometimes above speculum or just along pleural carina; $2 / 3$ or more of mesopleuron white $\ldots \ldots \ldots \ldots \ldots \ldots \ldots . \ldots . \ldots$

3. Malar space $0.80-0.85$ as long as basal width of mandible; scape entirely black; propodeum apicad of basal trans-carina uniformly pale fulvous .......... 20. D. pareia $\mathrm{n}$. sp. Malar space $0.48-0.58$ as long as basal width of mandible; scape largely white below; propodeum apicad of basal transcarina white with black markings $\ldots \ldots \ldots \ldots \ldots \ldots$

4. Temple 0.38 as long as eye at upper $1 / 3$; pronotal scrobe without wrinkles except for the short epomia; juxta-coxal carina absent; propodeal cristae large, strongly projecting, bluntly triangular; propodeum entirely black basad of basal transcarina ...................... D. aspila n. sp. Temple $0.50-0.60$ as long as eye at upper $1 / 3$; pronotal scrobe with numerous wrinkles in addition to the scarcely differentiated epomia; juxta-coxal carina almost complete but irregular at least on apical $1 / 2$; propodeal cristae weakly cuneate, low, broad, and scarcely projecting; propodeum basad of basal trans-carina black with a large white sublateral blotch ................... 18. D. picta Townes

5. Tyloids sharp carinae extending full length of several segments; lower metapleuron with moderately coarse punctures ....6 
Tyloids carinate but either obsolescent and almost impossible to see or, if fine and sharp, generally shorter than the length of their segments; lower metapleuron with fine, weak punctures .............................

6. Malar space 0.75 as long as basal width of mandible; clypeus moderately convex in profile; mesosternum usually entirely fulvous, sometimes partly black and rarely entirely black; epomia rather weak ..........22. D. acadia Cushman Malar space 0.83 as long as basal width of mandible; clypeus weakly convex in profile; mesosternum largely or entirely black; epomia moderately strong ....... D. rugosa Townes

7. Mesoscutum black with a pair of median white lines or with a median white blotch $\ldots \ldots \ldots \ldots \ldots \ldots \ldots \ldots . \ldots . \ldots$ Mesoscutum mostly or entirely fulvous, with or without a pair of median whitish dashes $\ldots \ldots \ldots \ldots \ldots \ldots \ldots$

8. Tyloids sharp longitudinal carinae on 4 segments but in most cases shorter than their segments; flagellum with a white band on about 5 segments; pronotum apicad of basal transcarina white with a broad black stripe along pleural carina almost to apex and black narrowly along basal trans-carina ........................ D. rufigaster Cushman

Tyloids hard to see, low, indistinct ridges extending about 0.3 the length of several segments; flagellum at most with a poorly defined postmedian brown section; propodeum apicad of basal trans-carina dull fulvous to yellowish or whitish and without black or with black only along basal transcarina ............................

9. White orbital ring interrupted on vertex and upper half of temple; pronotum white with a very large black apico-lateral area; mesopleuron black with white on subalarum and speculum and with more or less whitish stained fulvous on most of lower $1 / 3$ of mesepisternum behind prepectal carina as well as throughout on mesepimeron.17. D. sphenos n. sp. White orbital ring complete; pronotum wholly white; mesopleuron mostly whitish or stramineous to weakly brownish white, in some specimens with black on as much as anterior 1/3-1/2 below sub-alarum ..... 16. D. macula (Cameron) 
10. Eye about $75 \%$ surrounded with yellowish white, the whitish orbit being interrupted on upper part of temple; mesoscutum without a median pair of whitish dashes $\ldots \ldots \ldots \ldots \ldots$ D. brunnea Townes

Eye completely surrounded with yellowish white; mesoscutum with a median pair of whitish dashes $\ldots . \ldots \ldots \ldots . .$.

D. alabama Cushman

\section{Diapetimorpha macula (Cameron)}

SPECIMENS EXAMINED: 17 females, 4 males: BENTSEN PARK (Net: 1 female, 19 III '76; 1 male, 9 VI '76; 12 females, 1 male, 2-10 IX '76; 1 female, 29 XII '76); BOTANICAL GARDEN (Net: 1 female, 16 III '74; 1 female, 19 XII '76; Malaise: 2 males, 10-31 X '73; 1 female, XII '73).

HABITAT: Dark, damp woods; herbaceous undergrowth beneath Pithecellobium flexicaule; Celtis lindheimeri-C. pallida association.

DISTRIBUTION: Va. to Fla. west to Tex. and south to Veracruz state in México.

GEOGRAPHIC VARIATION: Townes (1962, p. 384-387) divides macula into several subspecies, among which my Valley material agrees most closely with $D . m$. macula, heretofore not recorded north of México.

PHAENOLOGY: Flies almost throughout the year with peak in September. Valley records include 2 females for March, 1 male for June, 12 females and 1 male for September, 2 males for October, and 3 females for December. North of the Valley macula is active between March and November.

\section{Diapetimorpha sphenos $\mathrm{n}$. $\mathrm{sp}$.}

(Fig. 9)

Holotype: female, USA (Texas: Hidalgo County, Bentsen Río Grande Valley State Park, 1-15 XI '76, Malaise Trap, C. C. Porter). (Townes). Paratypes: 1 female, 2 males, USA (Texas: Hidalgo County, Bentsen Río Grande Valley State Park, 1-15 V '76, Malaise Trap, C. C. Porter; Valley Botanical Garden at McAllen, X '73, Malaise Trap, C. C. Porter). (Gainesville, Porter).

FEMALE: Color: antenna black with much dull to pale brown on scape, and sometimes pedicel and base of first flagellomere, and 
with a ventrally interrupted white band on flagellomeres 4 (apically) to 9 and sometimes slightly onto base of 10; head black with palpi brownish white, mandible brownish white with dark brown on apical $1 / 4$, brownish white on mandibular condyle, dull brown on apical $1 / 3$ of clypeus, at times with a brownish median spot on face somewhat below antennal sockets, and with white broadly on most of frontal orbit; propleuron black; pronotum black with a broad white band on most of front margin except for hind corners, a large, broadly triangular white mark on median $1 / 3$ of dorsal margin which is contiguous medially with white band on front margin and which encloses a more or less well developed central brown area, and with a little pale brown on upper hind corner; thoracic dorsum black with tegula white, a pair of short median white stripes on mesoscutum in apical $1 / 3$ of notauli, scutellum shining ferruginous with a yellowish tinge, postscutellum yellowish to ferruginous white, and hind rim of meso and metanotal axillary troughs narrowly whitish to ferruginous; mesopleuron and mesosternum black with ferruginous on about ventro-posterior $2 / 3$ of mesepisternum, narrowly on adjacent mesosternum, and on most of mesepimeron as well as with white on much of subalarum and toward dorsum of mesepimeron; mesosoma otherwise uniformly ferruginous; gaster ferruginous with a trace of faint dusky staining on the more apical tergites and with a very large medioapical white blotch on tergite 7 and a similar but smaller white area on 8; legs ferruginous to stramineous with blackish anterior and posterior staining on hind trochanter and with 5th tarsomeres dusky; wings hyaline with fore wing faintly brown tinged and stigma rather pale brown.

Length of fore wing: $4.6-4.8 \mathrm{~mm}$. First flagellomere: $5.5-6.0$ as long as deep at apex. Clypeus: moderately convex in profile. Malar space: $0.62-0.64$ as long as basal width of mandible. Temple: $0.19-$ 0.22 as long as eye at upper $1 / 3$. Pronotum: scrobe extensively wrinkled. Mesoscutum: finely and densely punctate with a broad band of delicate transverse wrinkling along anterior $2 / 3$ of notauli, mostly internally, and with stronger longitudinal wrinkling between notauli on about their apical 1/3. Mesopleuron: in large part with strong wrinkling that is more or less regularly longitudinal above and more irregular below or which sometimes is longitudinally biased throughout. Lower metapleuron: with strong longitudinal wrinkling that becomes very irregular on dorso-posterior $1 / 2$; juxta-coxal 
carina obsolete, weakly suggested only near base. Propodeum: basal trans-carina rather strongly curved forward medially; apical transcarina curved far forward and slightly to markedly irregular medially, its cristae broadly and strongly projecting cuneate; surface with strong reticulate wrinkling that is finer basad of basal trans-carina. First gastric segment: postpetiole $1.1-1.3$ as wide apically as long from spiracle to apex. Ovipositor: sheathed portion $0.42-0.48$ as long as fore wing; tip $0.23-0.24$ as high at nodus as long from nodus to apex.

MALE: Color: scape pale brownish to whitish with a little dusky staining dorsad; pedicel dark brown with apex paler; flagellum dark brown, becoming gradually a little paler apicad; palpi white; mandible white with dark brown on apical 1/3; head black with white on clypeus, face, broad frontal orbits, very broad hind orbit of about $1 / 2$ of eye, and throughout from malar space to hypostomal carina; propleuron white; pronotum white with a very large black area apico-laterally; thoracic dorsum black with tegula white and with a large, transverse, anteriorly emarginate postmedian white blotch on mesoscutum, and with white on scutellum, postscutellum, and narrow hind margins of meso and metanotal axillary troughs; mesopleuron black with white on subalarum and speculum and with more or less whitish stained fulvous on most of lower 1/3 of mesepisternum behind prepectal carina as well as throughout on mesepimeron; mesosternum testaceous-stained white except black anteriad of prepectal carina; upper metapleuron white; mesosoma otherwise pale fulvous to yellowish with hind face of propodeum more whitish; gaster pale fulvous with dark brown to black on extreme base of petiole, on basal half of segment 2, and on basal $1 / 3$ of 3 , as well as with paler brown to equally dark brown or black on basal 1/4 of 4-6 and dusky on much of 7; fore leg with coxa, trochanter, and trochantellus white, femur and tibia pallid fulvous, and tarsus whitish with fifth segment dusky and a little dusky above on third and fourth segments; mid leg similar to fore leg but with light fulvous staining dorsad on coxa, trochanter, and trochantellus and with tarsus largely dusky except for whitish narrowly on tips and bases of segments 2-4 and with segment 1 dull fulvous grading into dusky on apical $1 / 2$ with tip whitish; and hind leg pale fulvous with considerable blackish on trochanter, sometimes slightly dusky on apex of trochantellus and base of femur, tibia a little dusky at base and dusky stained on most of apical 2/3 except below, and 
with tarsus blackish with dull white on base of first segment and pure white on apical $1 / 3$ of first segment and on all of segments 2-4; wings hyaline with stigma brownish.

Length of fore wing: $3.5-3.6 \mathrm{~mm}$. Flagellum: tyloids not clearly defined; first flagellomere 4.1-4.5 as long as deep at apex. Clypeus: moderately convex. Malar space: $0.55-0.65$ as long as basal width of mandible. Temple: $0.47-0.52$ as long as eye at upper 1/3. Pronotum: scrobe smooth, without wrinkles except for short epomia or sometimes with several oblique wrinkles in addition to epomia. Mesoscutum: smooth and polished with numerous, well spaced small punctures that become somewhat larger and denser anteriad. Mesopleuron: smooth and polished with small, scattered punctures and only a little longitudinal wrinkling limited to dorsal region behind subalarum. Lower metapleuron: smooth and polished with scattered small, weak punctures that become only a little larger and denser dorsad toward pleural carina; juxta-coxal carina defined for a short distance near base. Propodeum: basal trans-carina only weakly curved forward medially; apical trans-carina complete, advanced far forward medially, its cristae scarcely raised; surface smooth and polished basad of basal trans-carina, moderately wrinkled apicad of apical trans-carina. First gastric segment: postpetiole 0.84 as wide apically as long from spiracle to apex.

TYPES: The holotype is in the collection of Henry K. Townes, 5950 Warren Rd., Ann Arbor, Michigan. One male paratype has been donated to the Florida State Arthropod Collection (Division of Plant Industry, Entomology Bureau, Florida Department of Agriculture, Gainesville, Florida, 32602) and a male and female paratype are retained in the author's personal collection (301 N. 39th Street, McAllen, Texas, 78501).

RELATIONSHIPS: This species is close to $D$. macula but may be easily distinguished by the structural and chromatic characters given in the key.

FIELD NOTES: Sphenos has been collected only by Malaise Trap and appeared at both the Bentsen Park and Botanical Garden collecting stations. It is thus a species of shady woods, associated with large trees such as Pithecellobium flexicaule and Celtis lindheimeri.

Sphenos may have separate fall and spring generations, as there are records for October and November and again for May. 
SPECIFIC NAME: From the genitive of the Greek noun sphen (sphenos) or "wedge", in reference to the shape of the propodeal cristae.

\section{Diapetimorpha picta Townes}

SPECIMENS EXAMINED: 2 males, BENTSEN PARK (Net: 1 female, 17 III '76; 1 male, 17 III '77).

HABITAT: Serjania vines in Salix nigra woods along Río Grande. DISTRIBUTION: Previously recorded only from Florida and south Georgia (Townes, 1962, p. 387). Among material loaned by Townes is a male from Kansas (Clark County, 12 VI '60, R. L. Fischer). Picta thus probably ranges over the southeastern U.S. and into México.

\section{Diapetimorpha aspila $n . s p$.}

(Fig. 4)

Holotype: female, USA (Texas: Hidalgo County, Valley Botanical Garden at McAllen, XII '73, Malaise Trap, C. C. Porter).

FEMALE: unknown.

MALE: Color: antenna black with scape broadly white below, a little brown on apex of pedicel and base of first flagellomere, and a white annulus on flagellomeres 9-15; palpi white with a pale brownish tinge; mandible white with apical $1 / 3$ dark brown; head white with black on median $1 / 2$ of front and vertex, more broadly on occiput, on postocciput, and ventrad increasingly more narrowly along occipital carina to about its lower 0.1 ; propleuron white; pronotum black with a very broad white band throughout on anterior margin, a much narrower and apically attenuate white band on most of humeral margin, and a little white on upper hind corner; thoracic dorsum black with a large, more or less rectangular, anteriorly deeply emarginate postmedian white blotch on mesoscutum, and with white on scutellum, postscutellum, and hind rims of meso and metanotal axillary troughs; tegula white; mesopleuron black with white on subalarum and on most of its lower 3/4 apicad of prepectal carina, except for a large, irregular black blotch below speculum and for black in about upper 0.7 of pleural suture; mesosternum black on prepectus and otherwise white with a little brownish staining in front of mid coxae; upper metapleuron white except for black on its narrow lower $1 / 3$; lower metapleuron white 
with black irregularly along its anterior margin; propodeum basad of basal trans-carina entirely black and apicad of basal trans-carina white with a broad anteriorly gradually narrowed black blotch that reaches forward from gastric insertion about $2 / 3$ the distance to basal trans-carina as well as with a broad black stripe along about basal 7/9 of pleural carina; first gastric segment with white on basal $1 / 2$ of petiole above and laterally and on apical $1 / 2$ of postpetiole as well as with brownish yellow on most of petiole ventrally; gastric tergites 2-7 black with very broad white apical bands and tergite 8 and claspers brownish yellow; fore leg with coxa, trochanter, and trochantellus white, femur and tibia dull pale fulvous, and tarsus pale brownish with segments 3-5 blackish; mid leg with coxa white with a yellowish brown tint, trochanter yellowish white with considerable brown staining, trochantellus yellowish white, femur and tibia pale fulvous and tarsus blackish grading irregularly into dull fulvous on basal $1 / 2$ and with a little pale brownish on tips of segments 1-4; hind leg bright, deep fulvous on coxa, trochanter, trochantellus, femur and tibia and with considerable dark brown on trochanter, a little blackish on base of tibia, and slight dusky staining toward apex of tibia, and tarsus with segment 1 black on basal half and white on apical half, segments $2-4$ white, and 5 black; wings hyaline with stigma dark brown.

Length of fore wing: $5.0 \mathrm{~mm}$. Flagellum: first segment 4.25 as long as deep at apex; segments 12-15 with tyloides in the form of fine but sharp carinae that extend about 0.4-0.6 the length of each. Malar space: 0.58 as long as basal width of mandible. Clypeus: moderately strongly and asymmetrically convex, weakly nasute in lateral view. Temple: at upper $1 / 3$ about 0.38 as long as eye in lateral view. Pronotum: scrobe smooth and polished, without wrinkles except for the short epomia. Mesoscutum: smooth and polished with numerous tiny, well spaced punctures. Mesopleuron: mostly smooth and polished with small, scattered punctures. Lower metapleuron: smooth and polished with small, very well spaced punctures that are scarcely denser dorsad; juxta-coxal carina absent. Wing venation: intercubitus about 3.0 as long as width of radial vein. Hind femur: 5.1 as long as deep at middle. Propodeum: basad of basal trans-carina smooth and shining with numerous medium-sized punctures, laterad and behind basal trans-carina rather strongly and irregularly wrinkled; basal trans-carina almost straight; apical trans-carina forming broad and strongly projecting 
bluntly triangular cristae, between the cristae advanced far forward but, except for a short median segment, practically effaced. First gastric segment: postpetiole 0.91 as wide at apex as long from spiracle to apex; tergite smooth and shining with a few tiny, scattered punctures.

TYPE: The holotype is in the collection of Henry K. Townes, 5950 Warren Rd., Ann Arbor, Michigan, 48501.

RELATIONSHIPS: Aspila closely resembles $D$. picta but may be distinguished by the characters summarized in the key.

FIELD NOTES: Collected by Malaise Trap in a partially shaded Celtis lindheimeri-C. pallida thicket.

SPECIFIC NAME: from the Greek adjective aspilos or "unspotted", in reference to the uniformly black propodeal base of this species.

\section{Diapetimorpha pareia n. sp.}

(Fig. 7)

Holotype: male, USA (Texas: Hidalgo County, Valley Botanical Garden at McAllen, 1 I '76, C. C. Porter). (Townes). Paratype: male, USA (Texas: Hidalgo County, Bentsen Río Grande Valley State Park, 15-30 IV '76, Malaise Trap, C. C. Porter). (Porter).

FEMALE: unknown.

MALE: Color: antenna black with a pale yellow annulus on flagellomeres 9-18 or 19; palpi white; head white with black, preceded by a narrow brownish zone, on apical 1/3 of mandible, a small dusky spot just above dorsal corner of clypeus, a little dusky around anterior tentorial pits, and black on median $1 / 2$ of front and vertex, more broadly on occiput, on all but ventral corner of postocciput, and ventrad, increasingly more narrowly, on temple along occipital carina to about its upper 0.5 ; propleuron white; pronotum black with a broad white band on all but extreme hind corner of front margin, a narrow white band on anterior $2 / 3$ of humeral margin, and with white on upper hind corner, or sometimes white narrowly throughout on humeral margin; thoracic dorsum black with a large more or less rectangular postmedian white spot on mesoscutum, and with white on scutellum, postscutellum, and hind rims of meso and metanotal axillary troughs as well as with some yellowish staining anteriorly in metanotal axillary trough on each side of postscutellum; tegula white; mesosternum and mesopleuron pale yellow, becoming more nearly white anterio-dorsally on mesopleuron, as 
well as sometimes with a little brownish staining above subalarum, a large black area above speculum, and more or less black on dorsal 1/2 of prepectus; dorsal metapleuron and groove at base of propodeum yellow and sometimes with a little brownish staining on dorsal metapleuron anteriorly at about upper $1 / 3$; lower metapleuron pale yellow testaceous; propodeum pale fulvous with black basad of basal trans-carina in most of region between spiracle and area-basalis, which is dull testaceous or yellow grading into black apically and laterally; first gastric segment yellow with black above on petiole and basal $2 / 3$ of postpetiole, except for a broad median yellow stripe on basal $4 / 5$ of petiole; second gastric tergite black with a broad yellow apical band and pale fulvous on thyridia; succeeding tergites similar to second except that the apical yellow bands reach farther forward laterally; fore leg with coxa, trochanter, and trochantellus yellow with a little brown staining above on trochanter, femur and tibia pale testaceous, and tarsus testaceous grading into dusky or black on last three segments; mid leg similar to fore leg except that the coxa, trochanter, and trochantellus have a faint testaceous suffusion, the tibia sometimes becomes dusky above on apical $1 / 4$, and the tarsus varies from mostly blackish to dusky on segments $2-5$ and somewhat paler on 1; hind coxa, trochanter, trochantellus and femur rather intense shining testaceous with a brown streak ventro-anteriorly on base of coxa (absent in paratype) and some brown staining above toward base of trochanter, on apex of trochantellus, and on base of femur; hind tibia yellowish testaceous with a little dusky on base and blackish on apical $1 / 3$ or a little more, and hind tarsus white with black on basal 1/8 of first segment, at least laterally, and on apical 1/4 of last segment; wings hyaline with stigma dull brownish white.

Length of fore wing: 7.1-7.5 mm. Flagellum: first segment 3.94.3 as long as deep at apex; tyloids very weak, sometimes faintly detectable as longitudinal discontinuities on segments 10-16 which extend about $0.5-0.8$ the length of each segment. Malar space: $0.80-0.85$ as long as basal width of mandible. Clypeus: weakly convex in profile. Temple: 0.60 as long as eye at upper $1 / 3$. Pronotum: scrobe smooth and polished and without wrinkles except for the short epomia. Mesoscutum: smooth and polished with abundant tiny punctures separated by $4-5 \times$ their diameters. Mesopleuron: smooth and polished with numerous well spaced, tiny punctures and with a little longitudinal wrinkling above speculum. 
Lower metapleuron: mostly smooth and shining with many tiny, sparse punctures that become larger and denser, with a little intercalated wrinkling, only dorsad near the obsolete pleural carina; without juxta-coxal or, in paratype, with juxta-coxal carina defined only on basal 1/3. Propodeum: smooth and polished basad of basal trans-carina, otherwise rather coarsely and irregularly wrinkled; basal trans-carina almost straight; apical trans-carina in holotype irregularly traceable between the broad and moderately projecting triangular cristae and in paratype sharp but only slightly curved forward between the lower, more cuneate cristae. First gastric segment: postpetiole 0.87 as wide at apex as long from spiracle to apex; its surface smooth and polished with a few tiny, scattered punctures.

TYPE: The holotype is in the collection of Henry K. Townes, 5950 Warren Rd., Ann Arbor, Michigan, 48105 and the paratype in the collection of Charles C. Porter, 301 N. 39th St., McAllen, Texas, 78501.

RELATIONSHIPS: In habitus and color this species resembles $D$. picta and D. aspila but may be separated from both by its much longer malar space and by chromatic features such as its entirely black scape and uniformly pale fulvous propodeal base.

FIELD NOTES: Taken by sweeping Serjania vines in a partial clearing near the edge of a Celtis lindheimeri-C. pallida thicket and in a Malaise Trap located in deep shade beneath a large Pithecellobium flexicaule.

SPECIFIC NAME: From the Greek noun pareia or "cheek," in reference to the long malar space.

\section{Diapetimorpha introita (Cresson)}

SPECIMENS EXAMINED: 15 females, 12 males: BENTSEN PARK (Net: 3 females, 1 male, 12-20 III '77; 1 male, 7 IX '76); BOTANICAL GARDEN (Net: 1 female, 17 I '75; 6 females, 4 males, 12-20 III '77; 1 male, 5 IV '74; 1 male, 16-30 V '74; 1 male, 30 VIII '76; 1 male, 1 IX '73; 1 female, 9 IX '76; 4 females, 20-31 XII '74; Malaise: 1 male, IX '73; 1 male, $X{ }^{\prime} 73$ ).

HABITAT: Open, sunny places; tall grass at edge of fields and thickets; herbaceous growth in abandoned orange groves; occasionally enters dense woods.

Distribution: N.C. to Tex. and into Nuevo León, México. 
PHAENOLOGY: Peaks in spring and fall; possibly absent in summer. Valley records include 1 female for January, 9 females and 5 males for March, 1 male for April, 1 male for May, 1 male for August, 1 female and 3 males for September, 1 male for October, and 4 females for December. North of the Valley introita flies from mid-spring to early fall but disappears by July in most of Texas.

\section{Diapetimorpha acadia Cushman}

SPECIMENS EXAMINED: 1 female, 4 males: BOTANICAL GARDEN (Net: 1 female, 1 male, 12 III '77; 1 male, XII '73; Malaise: 2 females, III '74).

HABITAT: Exposed areas to dense woods; weeds in bright sun; partially shaded hedge row; Celtis lindheimeri-C. pallida thicket.

DISTRIBUTION: Va. to Tex. and Mexican state of Coahuila.

PHAENOLOGY: Valley records are for December and March. North of the Valley it flies from late spring to early fall and peaks between 15 August and 15 September.

\section{Genus Listrognathus}

\section{Listrognathus glomerata Townes}

Townes (1962, p. 424-425) gives one undated record of this species from "Cameron County, Texas". I have not collected glomerata personally.

Glomerata ranges from New Jersey to south Texas and flies mostly from early spring to late fall.

\section{Listrognathus rufitibialis Cushman}

SPECIMENS EXAMINED: 19 females, 3 males: BENTSEN PARK ( Net: 2 females, 12-20 III '77; 2 females, 23-30 XII '76); BOTANICAL GARDEN (Net: 6 females, 9-11 I '76; 1 female, 16 I '75; 1 female, 24 I '76; 1 male, 12-20 III '77; 1 male, 16-30 V '74; 1 female, 19 XII '76; 4 females, 22-28 XII '75; 2 females, 1 male, 20-31 XII '73).

HABITAT: Exposed to shaded areas; fields at edge of woods; Serjania vines in woodland clearings; in bright sun among small herbaceous plants on paths through open brushland.

DISTRIBUTION: Eastern U.S. from N. J., Ind., and Okla. southward. 
PHAENOLOGY: Valley populations peak in winter, my data including 8 females for January, 2 females and 1 male for March, 1 male for May, and 9 females and 1 male for December. North of the Valley it flies mostly from June to September.

\section{Genus Mallochia}

\section{Mallochia agenioides Viereck}

SPECIMENS EXAMINED: 10 males: BENTSEN PARK (Net: 1, 23 I '76; Malaise: 1, 16-31 I '76; 1, 1-15 II '76; 2, 16-28 II '76; 2, 1-15 V'76; 1, 16-31 VIII '76; 2, 1-15 IX '76).

HABITAT: Most Valley specimens were collected by a Malaise Trap installed in deep woods under a large Pithecellobium flexicaule. Farther north, agenioides often is found in grassy, overgrown meadows.

DISTRIBUTION: R.I. to Ks. and south to Florida. These are the first records for Texas.

PHAENOLOGY: Valley records are for January, February, May, August, and September. Elsewhere agenioides flies mostly from mid-spring to mid-summer.

\section{Mallochia frontalis Townes}

SPECIMEN EXAMINED: 1 male, Bentsen Park, 1-15 IX '76.

HABITAT: Caught by Malaise Trap in dense woods under shade of a large Pithecellobium flexicaule.

Distribution: N.J., Md., Va., N.C., Ks., Tex.

PHAENOLOGY: North of the Valley frontalis flies between March and August.

\section{Genus Lymeon}

The Valley has three Lymeon, of which one here is recorded for the first time from the United States.

\section{KEY TO THE U.S. LYMEON \\ (Females only)}

1. Mesoma black with profuse white markings ...........2 Mesosoma fulvous or ferruginous, with or without white mark-

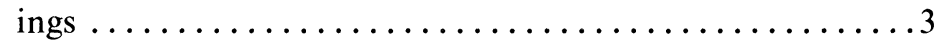


2. Mesoscutum with a single median white spot; lateral lobe of mesoscutum throughout with medium-sized, sharp, moderately dense punctures ......27. L. cinctiventris (Cushman) Mesoscutum with a pair of submedian white stripes; lateral lobe of mesoscutum, except on about basal $1 / 3$, sparsely punctate ..................... 28. L. orbus (Say).

3. Discoidella completely absent; lateral lobe of mesoscutum polished; second gastric tergite black with a broad white apical band; fore wing without dark cross bands .............. .......................... bicinctus (Cresson).

Discoidella well developed; lateral lobe of mesoscutum mat; second gastric tergite wholly fulvous; fore wing with a median and subapical dark cross band $\ldots \ldots \ldots \ldots \ldots \ldots \ldots . \ldots$

4. Clypeus prolonged ventrally as a conical point; malar space 1.5 as long as basal width of mandible; head mostly fulvous and without black areas; no white on pronotum, subalarum, and propodeal cristae ................ L. nasutus (Pratt).

Clypeus strongly convex but not pointed ventrally, the apical margin almost truncate; malar space 0.66 as long as basal width of mandible; head mostly black, sometimes with clypeus and face fulvous; white on broad anterior margin of pronotum, subalarum, and propodeal cristae ........... ....................29. L. leucosoma (Cameron).

\section{Lymeon cinctiventris (Cushman)}

SPECIMENS EXAMINED: 1 female, 4 males: BENTSEN PARK (Net: 1 female, 29 XII '76); BOTANICAL GARDEN (Net: 2 males, 16 I '75;

1 male, 1 IV '75; 1 male, 24 XII '74).

HABITAT: Damp area in tall grass beneath Salix nigra and Acacia farnesiana near irrigation canal.

DisTRIBUTION: Md. to Fla. and west to Tex.

PHAENOLOGY: Valley records are for December, January and April. Farther north, cinctiventris flies between April and September.

\section{Lymeon orbus (Say)}

SPECIMENS EXAMINED: 3 females: BENTSEN PARK (1, 19 I '76); BOTANICAL GARDEN (1, 1 IV '75; 1, 30 XII '74). 
HABITAT: Herbaceous undergrowth in dense woods.

DistRibuTION: N.Y. to Fla. west to Wis., Ks., Tex., and Nuevo León state of México.

GEOGRAPHIC VARIATION: Specimens from México and the Valley have the female hind coxa white with a black area above, black narrowly throughout on base, and with a large black blotch on basal half anterio-ventrally. In material from eastern North America the female hind coxa is fulvous with a more or less well developed whitish dorsal blotch.

PHAENOLOGY: Valley records are for December, January and April. Elsewhere it flies mainly from spring to fall.

\section{Lymeon leucosoma (Cameron)}

(Fig. 3)

FEMALE: Color: scape pale fulvous; pedicel pale fulvous to dusky; flagellum with first segment pale fulvous to dull brownish grading into blackish on apical $1 / 2$, second and third segments black with a little brownish below, fourth black with a little white on apical $1 / 3$, fifth through eighth white with some pale brownish below, ninth black with white on basal 1/3 above and brownish below, and succeeding segments dull brownish with some dusky staining on the more basal ones and paler apicad; head black with pale brown on mandibular condyles and face and clypeus sometimes largely stained with pale fulvous and with mandible mostly white on basal $2 / 3$ but on apical 1/3 grading through pale brown into black; palpi whitish brown; mesosoma rather opaquely pale fulvous with some black basad in mesonotal axillary trough, a little dusky staining in some other areas, and with white broadly on all but about lateral 1/5 of front margin of pronotum, dully anteriad on tegula, on most of subalarum, vaguely toward top of mesepimeron, sometimes weakly on sides of scutellum and on postscutellum, and on propodeal cristae; gaster rather opaquely pale fulvous with slight dusky tinging; legs pale fulvous, duller on tibiae and tarsi, and dusky on fifth tarsomeres; wings hyaline, the fore wing with a median brown crossband occupying basal $1 / 2$ of discocubital cell, extreme base of second discoidal cell, about apical 3/4 of first brachial cell and extending briefly into base of second brachial cell, as well as with a subapical brown cross band that covers apical 1/4 of radial cell, almost median $1 / 2$ of third cubital cell, and about dorso-median $1 / 3$ of third discoidal cell; stigma brownish white. 
Length of fore wing: $4.5-5.8 \mathrm{~mm}$. First flagellomere: $6.1-7.5$ as long as deep at apex. Clypeus: strongly and asymmetrically convex with apical face distinctly shorter and more strongly declivous than basal. Malar space: 0.66 as long as basal width of mandible. Temple: 0.36 as long as eye at upper $1 / 3$; moderately and directly to a little convexly receding; dully to rather strongly shining with variably developed fine micro-reticulation and more or less numerous small, obscure punctures. Pronotum: humeral margin scarcely swollen; epomia more or less well defined in scrobe among some other variably developed irregular wrinkles. Mesoscutum: notauli weakly defined on about basal 1/3 of mesoscutum and traceable almost to apex as a wide band of oblique rugosities; surface mat with fine micro-reticulation and stronger wrinkling along notauli and rearward on central lobe as well as with numerous, medium sized, shallow and obscure, mostly subadjacent or sparser punctures. Mesopleuron: mostly mat and rather finely reticulately wrinkled but with some discrete punctures on prepectus and on dorsal 1/3; speculum smooth and polished. Lower metapleuron: with rather strong reticulate wrinkling that sometimes becomes more regularly oblique ventro-posteriad. Wing venation: areolet $0.68-0.76$ as high as part of second recurrent above bulla, first intercubitus reclivous; discoidella well developed, upper part of nervellus 1.5-1.8 as long as lower; brachiella well developed. Fore tibia: only slightly swollen. Propodeum: median part of basal groove with some sharp longitudinal ridges; spiracle 1.2 as long as wide; cristae small but strongly projecting subligulate tubercles, apical carina otherwise lacking. First gastric segment: postpetiole 1.3 as wide apically as long from spiracle to apex, its surface a little dully shining with well defined micro-reticulation; dorso-lateral carina traceable throughout and mostly sharp. Second gastric tergite: thyridium transverse; surface mat and finely reticulate with small, sparse, obscure punctures emitting short, widely spaced setae. Ovipositor: sheathed portion 0.34 as long as fore wing; tip 0.26 as high at nodus as long from nodus to apex and directly tapering between nodus and apex.

MALE: Unknown.

SPECIMENS EXAMINED: 4 females, USA (Texas: Hidalgo County, Valley Botanical Garden at McAllen, 12-27 I '74, C. C. Porter; Bentsen Río Grande Valley State Park, 19 I '76, C. C. Porter); MEXICO (Jalisco: Guadalajara, 17 VII '51, H. E. Evans). (Porter, Townes). 
DISCUSSION: These are the first records of leucosoma from the United States and México, the species having been cited previously only from Guatemala (Cameron, 1886, p. 259).

A homotype from Guadalajara, México loaned by H. K. Townes differs from my Texas material only in having the tegula a little more broadly white, the sides of the scutellum white, and the postscutellum white.

One of the Valley specimens was collected in the humid "Sunken Garden" at the Valley Botanical Garden, where it was swept from weeds at the edge of a thicket dominated by Ehretia anacua. The other was taken at Bentsen Park along the banks of the Río Grande in Serjania vines beneath Salix nigra and Celtis lindheimeri.

\section{Genus Acerastes}

30. Acerastes pertinax (Cresson)

SPECIMENS EXAMINED: 87 females, 92 males: BENTSEN PARK (Net: 3 females, 12-13 I '76; 3 females, 19 I '76; 3 females, 18-19 III '76; 1 male, 17 VI '73; 2 females, 1-13 VI '76; 1 female, 30 VIII '76; 1 female, 7 IX ' 76; 2 females, 27 XII '75; 6 females, 29-30 XII '76; Malaise (1976): 4 males, 15-30 IV; 5 females, 10 males, 1-15 $\mathrm{V}$; 1 female, 20 males, $16-31 \mathrm{~V}$; 1 male, 1-15 VI; 1 female, 16-30 VI; 1 male, 1-15 VII; 1 male, 16-31 VII; 2 males, 16-31 VIII; 5 males, 1-15 IX; 1 female, 2 males, 1-15 X; 6 males, 16-31 X; 1 female, 1 male, 1-15 XI; 1 female, 1 male, 16-30 XI; 1 male, 16-31 XII); BOTANICAL GARDEN (Net: 1 female, 5 I '75; 1 female, 18 I '75; 1 female, 26 I '76; 2 females, 1 male, 12-21 I '76; 4 females, 1 male, 17-24 III ' 74 ; 1 female, 5 IV '75; 1 male, 16-30 V' $74 ; 1$ male, 1 VI '75; 5 males, 1 IX '76; 1 female, 18 XII '76; 9 females, 1 male, 20-31 XII '74; Malaise (1973): 3 females, 18 males, X; 26 females, 8 males, XI; 9 females, XII).

HABITAT: Open to dense scrub or woods with abundant ground cover of grasses, forbs, or vines; gallery woods; Celtis lindheimeriC. pallida association; etc. Townes (1962, p. 405) gives the "usual habitat" of pertinax as "weedy fields or meadows" but it rarely enters such areas in south Texas.

DISTRIBUTION: Md. to Fla. and Tex. south to Brasil; Cuba, Jamaica.

PHAENOLOGY: Valley populations fly almost throughout the year with a spring peak in March-May and a fall maximum from Sep- 
tember to January. Monthy totals include 11 females and 1 male for January, 7 females and 1 male for March, 1 female and 4 males for April, 6 females and 31 males for May, 3 females and 3 males for June, 2 males for July, 1 female and 2 males for August, 5 females and 6 males for September, 4 females and 26 males for October, 28 females and 10 males for November, and 25 females and 2 males for December. All but 50 of the 179 specimens were collected by Malaise Traps. Pertinax shows some fluctuation in abundance from year to year. Malaise Trap surveys in the '73-'74 season and in 1976 have obtained 64 and 65 specimens respectively, while hand collecting accounted for 18 specimens in '73-'74, 7 in '74-'75, 20 in '75-'76, and 5 so far in '76-'77.

In the eastern U. S. pertinax flies mainly during August and September but in subtropical latitudes is more or less active all year.

\section{Genus Polycyrtidea}

\section{Polycyrtidea limitis Cushman}

SPECIMENS EXAMINED: 17 females, 17 males: BENTSEN PARK (Net: 1 male, 3 I '76; 1 female, 2 males, 12-13 I '76; 3 females, 2 males, 19 I '76; Malaise: 1 male, 1-15 IV '76; 1 male, 1-15 V'76;

BOTANICAL GARDEN (Net: 1 male, 7 I '75; 1 female, 2 males, 10-11 I '76; 1 male, 18 I '76; 1 female, 1 male, 18-22 I '76; 2 females, 12-21 I '74; 1 male, 16-30 V '74; 2 females, 26 XII '75; Malaise: 1 female, I '74; 4 females, 4 males, III '74; 1 male, XII '73); SANTA ANA NATIONAL WILDLIFE REFUGE (Net: 1 male, 24 XII '75).

HABITAT: Shaded, weedy places; Serjania vines in gallery woods; in tall grass beneath large Celtis lindheimeri.

DISTRIBUTION: Lower Río Grande Valley to Costa Rica.

PHAENOLOGY: Most abundant in January but flies almost throughout the year. My records include 10 females and 9 males for January, 4 females and 4 males for March, 1 male for April, 2 males for May, and 3 females and 1 male for December. Townes (1962, p. 407) gives two additional Valley records: 1 female, 30 July, Hidalgo County and 1 male and 1 female, September, Brownsville.

Limitis may vary in numbers from year to year, since 4 specimens were taken in '73-'74, 10 in '74-'75, 18 in '75-'76, and 2 in '76-'77. 


\section{Genus Pachysomoides}

32. Pachysomoides stupidus (Cresson)

SPECIMEN EXAMINED: 1 female, Bentsen Park, 24 XII ' 75.

HABITAT: Netted from Ulmus crassifolia at edge of forest trail.

DISTRIBUTION: N.C. to Fla., Tex., and south to Brasil.

PHAENOLOGY: North of the Valley stupidus flies mostly between between August and October.

\section{Pachysomoides fulvus (Cresson)}

SPECIMENS EXAMINED: 5 females: BENTSEN PARK (Net: 1, 12-20 III '77; 1, 29 XII '76); BOTANICAL GARDEN (Net: 26 I '75; 1, 12-20 III '77; 1, 20-31 XII' '73).

HABITAT: Undergrowth of well shaded woods; dense weeds in untended orange grove.

DISTRIBUTION: U.S. and southern Canada to México and Cuba.

PHAENOLOGY: North of the Valley fulvus is active mainly from early summer to mid-fall but, in mild years, still may be flying up to December and January as far north as Maryland, Nebraska, and British Columbia.

\section{Genus Messatoporus}

34. Messatoporus discoidaloides (Cresson)

SPECIMENS EXAMINED: 4 females, 5 males: BENTSEN PARK (Net: 2 females, 13-19 I '76; 1 male, 27 XII '75; 1 female, 29 XII '76; Malaise: 1 male, 1-15 IX '76); BOTANICAL GARDEN (Net: 2 males, 12-20 III '77; 1 female, 1 IV '75; 1 female, 19 XII '76).

HABITAT: Shaded places; Serjania vines in Celtis-Salix gallery woods; Celtis lindheimeri-C. pallida association.

DISTRIBUTION: Quebec and Minn. south to S.C. and Tex.

PHAENOLOGY: Most common in the Valley from December to early April. Farther north it flies between May and November.

Valley populations vary in abundance from year to year, as my data include no specimens for '73-'74, 1 for ' $74-75,3$ for ' $75-' 76$, and 5 for ' 76 -' 77 .

Genus Agonocryptus

35. Agonocryptus discoidaloides (Viereck) 
SPECIMENS EXAMINED: 97 females, 133 males: BENTSEN PARK (Net: 1 female, 12 I '76; 3 males, 17-19 III '76; 2 males, 12-20 III '77; 2 males, 8-10 IX '76; 3 males, 29 XII '76; Malaise (1976): 1 male, 1-15 II; 1 female, 4 males, 15-30 IV; 1 male, $16-31$ V; 5 males, 16-31 VII; 7 males, 1-15 VIII; 1 male, 16-31 VIII; 3 males, 1-15 IX; 8 males, 16-30 IX; 7 males, 1-15 X; 9 males, 16-31 X; 1 male, 1-15 XI; 1 female, 2 males, 16-30 XI; 1 female, 1 male, $1-15$ XII); BOTANICAL GARDEN (Net: 10 females, 7 males, 12-21 I '74; 2 females, 1-15 I '75; 6 females, 16-21 I '75; 13 females, 2 males, 1-15 I '76; 10 females, 2 males, 15-24 III '74; 2 females, 28 III '75; 1 male, 15 III '76; 15 females, 16 males, 12-20 III '77; 2 females, 1 male, 2-5 IV '75; 1 female, 1 male, 17-24 V' 74; 1 female, 23 VIII '73; 1 male, 30 VIII '75; 1 male, 7 IX '76; 13 females, 13 males, 20-31 XII '73; 5 females, 3 males, 20-31 XII '74; 3 females, 2 males, 23-23 XII '75; 1 female, 18 XII '76; Malaise (1973): 3 males, X; 3 females, 15 males, XI; 2 females, 1 male, XII '73).

HABITAT: In or at edges of moderately to deeply shaded woods, especially where there are dead trees, shrubs, or vines; sometimes abundant around fallen Celtis lindheimeri; in winter visits Condalia obovata shrubs in bright sun; on Serjania vines or herbaceous undergrowth in woods; often in orange groves on dead branches of frost-damaged citrus trees. Flies in open during winter and keeps to deep shade in hotter months. Males fly much more actively than females.

Distribution: N.H. and Wis. to Fla. and south Texas.

PHAENOLOGY: Valley populations peak between December and March but show some adult activity throughout the year. Monthly totals include 36 females and 11 males for January, 1 male for February, 27 females and 24 males for March, 3 females and 5 males for April, 5 males for July, 1 female and 9 males for August, 14 males for September, 19 males for October, 3 females and 19 males for November, and 26 females and 24 males for December. Of the 230 specimens, 76 ( 8 females and 68 males) were obtained by Malaise Traps. Discoidaloides fluctuates in numbers from year to year. Malaise Trap surveys in the '73-'74 season and in 1976 have obtained 24 and 52 specimens respectively, while hand collecting yielded 66 specimens in '73-'74, 19 in '74-'75, 21 in '75-'76, and 40 in '76-'77.

North of the Valley, discoidaloides flies mainly between April and October. 


\section{CONCLUSIONS}

\section{Zoogeography}

The 18 Valley mesostenine genera fall into three zoogeographic categories: Neotropic, Sonoran, and Holarctic. Neotropic genera are Latin American taxa with centers in the Brasilian Highlands, the Andean Cloud Forests, and the mountains of Middle America. The Sonoran group includes genera which originated along the Madro-Tertiary geoflora in the southwestern U.S. and northern México. The Holarctic element is circumpolar with maximum development in Temperate Deciduous Forests. Ten Valley genera are Neotropic: Cryptanura, Bicristella, Diapetimorpha, Mallochia, Lymeon, Acerastes, Polycyrtidea, Pachysomoides, Messatoporus, and Agonocryptus; four genera are Sonoran: Joppidium, Lanugo, Compsocryptus, and the Longicaudis group of Mesostenus; and five are Holarctic: Gambrus, Trychosis, the Transfuga group of Mesostenus, Listrognathus, and Trachysphyrus.

The Neotropic group requires special comment. This fauna predominates at the generic level, includes 22 of the 35 species reported, and accounts for 543 of the 679 specimens collected. Although the modern Neotropic radiation is centered in Latin American humid forests, only one of the genera cited, Bicristella, reaches its northern limit in the Valley; all others range farther into North America, where they inhabit principally the southeast. This northeastern group seems descended from a larger and more pervasive Middle and North American Tertiary fauna that was pushed south by Pleistocene glaciations. During glacial maxima, a few of these Neotropic elements survived in the southeastern U.S., while many retreated southwest into the more hospitable lower latitudes of Middle America. Interglacials allowed some expansion from Pleistocene refugia but the accompanying aridity in subtropic latitudes has slowed movement of moisture-loving ichneumonids. Thus, southeastern isolates have expanded with the Temperate Deciduous Forest and Southern Pine-Oak Forest as far north as Maryland or New Jersey and southwest into Texas, while some Mexican species have followed subtropical deciduous woods into Texas. However, the semiarid scrub now covering much of south Texas and northeast México has prevented massive interchange between the present-day Middle American and southeast North American Neotropic faunas. 
The Valley is a comparatively humid refugium surrounded by more arid habitats and located near the southwest limit of interglacial expansion for North American Neotropic species and close to the northeast limit for most Middle American species. Its Neotropic mesostenines are thus of complex distributional affinities. Four species, Cryptanura compacta, C. lamentaria, Lymeon leucosoma, and Polycyrtidea limitis, are Middle American and range from the tip of Texas to Central America. Cryptanura vallis, Bicristella texana, Diapetimorpha sphenos, D. aspila, and D. pareia are apparently endemic to the Valley but almost certainly will be found also in México when that poorly known fauna has been better collected. Acerastes pertinax and Pachysomoides stupidus extend all the way from Brasil to the southeastern U.S. On the other hand, Diapetimorpha picta, Mallochia agenioides, M. frontalis, Lymeon cinctiventris, Messatoporus discoidalis, and Agonocryptus discoidaloides are mainly eastern North American and reach their southern limit in the Valley. Diapetimorpha macula, $D$. introita, D. acadia, and Lymeon orbus likewise are centered in the Atlantic and Gulf states but range south a variable distance into México and Pachysomoides fulvus extends over the entire U.S. and well into México. Obviously, Pleistocene alteration of glacials and interglacials, as well as wetter and drier epochs within interglacials, have produced in the Valley a multiple overlap of northern and southern Neotropic mesostenines.

Valley mesostenine genera show extremely wide affinities. Cryptanura, Diapetimorpha, Mallochia, Lymeon, Acerastes, Pachysomoides, Messatoporus, and Agonocryptus range from the northeastern U.S. to subtropical Argentina, Polycyrtidea from Texas and Florida to Argentina, and Bicristella from Texas to Argentina. The 11 Neotropic mesostenine genera represented in the eastern U.S. all reach Argentina. Of the 34 genera found in Middle America, 33 cover at least a large part of South America also, while only one is endemic. About 20 more Neotropic mesostenine genera are endemic to South America. The Neotropic mesostenines thus seem to have evolved in South America during the Tertiary and to have spread northward massively in those warmer and wetter times. The modern Middle American fauna, generically, is a vast sample of the South American and the North American fauna a decimated vestige of the same stock. In the Tertiary, when humid forests covered much of North America below 40 degrees N. Lat. and 
when temperatures there, if scarcely tropical, were milder than at present, most of the Middle American mesostenine genera probably ranged far up the Gulf and Atlantic coasts. All of these moisture rather than temperature-controlled taxa tolerate winters with repeated frosts (as shown by their present-day altitudinal and latitudinal distribution in México) and, in fact, there are few, if any, Neotropic mesostenines which are "tropical" in the sense of requiring frost-free winters. This is why a fair number of Neotropic mesostenines survived glaciation in the southeastern U.S. This is also why the Valley should be viewed not only as a presentday northern outpost of the main Neotropic fauna but also in historical perspective as an area once situated deep within the vaster Tertiary Neotropics.

\section{Comparison with other Neotropic Deserts}

Recent hand collecting surveys in the Peruvian Coastal Desert (Porter, 1975b) and net and Malaise sampling in the northeast Argentine Subandino (Porter, 1975a) allow comparison of Valley mesostenines with those of two ecologically somewhat similar areas in remote parts of the Neotropics.

The Peruvian Desert reaches from south Ecuador to north Chile on the Pacific Coastal Plain and adjacent Andean foothills of western South America. Its rainfall varies from $80 \mathrm{~mm}$. per year in northern Perú to $0.5 \mathrm{~mm}$. at Arica, Chile but, near the coast, massive fogs supply additional humidity. This desert is frost-free, at least on the Coastal Plain, but the cold Humboldt Current running just off shore keeps temperatures moderate (at Arica, Chile the summer day-night range is about 20-30 degrees $C$. and the winter range approximately 10-22 degrees $\mathrm{C}$.). Thus we confront the paradox of a humid but almost rainless, cool but frost-free tropical desert.

Hand collecting during June-July of 1974-'76, mainly around Chiclayo, Trujillo, and Lima, Perú and Arica, Chile, has obtained from this desert in fertile valleys between sealevel and $2000 \mathrm{~m}$. a mesostenine fauna of 12 genera and 31 species. There are nine Neotropic genera (Biconus, Cyclaulus, Diapetimorpha, Basileucus, Lymeon, Acerastes, Polycyrtidea, Messatoporus and Agonocryptus), one Pantropic genus (Baltazaria), two Sonoran genera (Compsocryptus, Mesostenus of the Longicaudis group), and two Holarctic genera (Trachysphyrus, Mesostenus of the Transfuga group). 
Note that all these genera except Biconus, Cyclaulus, Basileucus, and Baltazaria are shared with the Valley. A simple index of affinity (Odum, 1971, p. 144) thus gives 0.606 (out of a possible 1.000) as the degree of similarity between the Valley and Coastal Desert mesostenine faunas. Actually, the real value probably approaches 0.777 , since four more Valley genera (Cryptanura, Bicristella, Mallochia, and Pachysomoides) occur also in the Ecuadorian rainforests and Andean cloud forests, so that they very likely penetrate the northern fringes of the desert.

The northwest Argentine Subandino of Salta, Tucumán, Catamarca, and La Rioja provinces resembles the Valley because it is in subtropical latitudes where many Neotropic taxa approach their distributional limits. However, the Subandino differs from the Valley by its inland location and relatively high altitude (study sites between 900 and $2000 \mathrm{~m}$.). Thus it has a much cooler temperature regimen that includes frequent winter frosts (annual average temperature 13-15.5 degrees C. vs. 23.4 degrees C. for the Valley). Moreover, the Subandino is a genuine semidesert with only $80-250 \mathrm{~mm}$. of rain per year (vs. $669 \mathrm{~mm}$. for the Valley).

Three years' use of 10 Malaise Traps and frequent collecting trips at all seasons between 1966 and 1972 obtained from the northwest Subandino a mesostenine fauna of 10 genera and 33 species, including seven Neotropic taxa (Dotocryptus, Diapetimorpha, Basileucus, Polycyrtidea, Polycyrtus, Messatoporus, and Agonocryptus), two Sonoran genera (Compsocryptus and Mesostenus of the Longicaudis group), and two Holarctic genera (Trachysphyrus and Mesostenus of the Transfuga group). Considering Polycyrtus almost certainly present in the Valley (it is in the eastern U.S. and northeast México), we get for the Valley and the Subandino a similarity index of 0.580 , one surprisingly high for two localities separated by about 42 degrees of latitude. In fact, since the Valley genera Cryptanura, Bicristella, Mallochia, Pachysomoides, and Joppidium reach at least the borders of the Subandino in northwest Argentina, the index of similarity eventually could prove as high as 0.8000 .

With regard to the Neotropic element, the above comparison of south Texas, coastal Peruvian, and Subandean mesostenines, only reemphasizes the vast South and Middle American distributions of so many of these genera. Species, of course, differ widely from place to place but at the generic level we find remarkable similarity 
between faunas as distant as the south Texan and the northwest Argentine. This correspondence between Texan, Peruvian, and Argentine arid-adapted mesostenine communities also shows that the same versatile genera tend to survive anyplace in Middle and South America where local conditions become dry enough to eliminate the wet forests which are the optimum habitat for most Neotropic mesostenines. Almost equally, it suggests a correlation between dry and cold tolerance, since nine of the ten Neotropic genera that reach well north in the eastern U.S. also occur in one or more of the dry areas studied (Cryptanura, Polycyrtus, Diapetimorpha, Lymeon, Mallochia, Acerastes, Pachysomoides, Messatoporus, and Agonocryptus).

Sonoran mesostenines also show much affinity among the three study areas. These genera are centered in México and the southwestern U.S. and evolved there in response to increased aridity and orogeny which affected that region in the latter half of the Tertiary. The Valley has four Sonoran taxa (Joppidium, Lanugo, Compsocryptus, and Mesostenus of the Longicaudis group) and two of these, Compsocryptus and the Longicaudis group of Mesostenus, are the only Sonoran mesostenines known from the Peruvian Desert and the Subandino. However, Lanugo reaches the Peruvian Andes and so might be found on the coast and Joppidium possibly enters both deserts, since it is known from Ecuador and turns up again in the Argentine Chaco. Most of these genera favor semiarid habitats, from thorn scrub to subtropical deciduous forests, and doubtless extended their distributions in the driest parts of the Tertiary and during interglacial xerothermic episodes. The present moderately wet interglacial has produced some notable Sonoran disjunctions, such as the above-mentioned case of Joppidium and that of Compsocryptus, which has many species in the western U.S. and México, a single representative in Florida and Cuba, an isolated species in the Peruvian Coastal Desert, and another disjunct species in northern Argentina.

The Holarctic element, consisting mainly of genera adapted to temperate forests, shows more discontinuities among Middle and South American arid zones than do the Sonoran and Neotropic faunas. Gambrus, Trychosis, and Listrognathus reach only as far south as the Valley or northern México. On the other hand, Trachysphyrus and the Transfuga group of Mesostenus occur in all three study areas. The Transfuga group is mainly Holarctic 
and Andean, reaching its austral limit in northern Argentina and including only three or four South American species. Trachysphyrus, in contrast, has a big Holarctic fauna plus a massive endemic South American radiation of more than 150 species centered in mountainous and/or semiarid to arid parts of the southern half of the continent. Thus the Subandino has 21 Trachysphyrus, the Coastal Desert 12, but the Valley only one. Interestingly, the south Texan species, T. mesorufus, is a member of the Planosae group, the only Trachysphyrus stock of South American origin to have invaded Middle and North America. The heterogeneous distributional patterns of Holarctic genera represented in the Valley show that this element has penetrated Middle and South America in different expansions at widely separated times. Trachysphyrus, because of its huge endemic South American fauna, probably had reached the southern continent by the middle or late Tertiary (Raven and Axelrod, 1975, p. 422 point out that even by the late Cretaceous the "northern Andes" were "beginning to approach their modern configuration" and thus could have served all through the Tertiary as a suitable habitat for temperate-adapted genera invading from the north.). The Transfuga group of Mesostenus, mainly Holarctic and in South America practically confined to the Andean region excluding Chile, doubtless moved south with Pleistocene glaciations. Finally, Gambrus, Trychosis, and Listrognathus, which only reach northern México perhaps were pushed as far as the Valley only by the most recent and severest Wisconsin glaciation.

\section{PhaENOLOGY}

Hand collecting and Malaise Trap records of Lower Río Grande Valley mesostenines obtained between June 1973 and March 1977 are summarized in Table 1.

Since hand collecting was possible only between 25 August-9 September, 18 December-25 January, 11-12 March (1-8 April in 1975) and 16 May-10 June, the data furnished in Table 1 show strong bias toward those periods. Fieldwork during February, October, and November, in particular, doubtless would have shown that these months have much larger mesostenine faunas than suggested in the table. Nonetheless, the phaenology emerges as unimodal and invernal with an impressive peak that extends from December to March and includes 390 of the 679 specimens and 

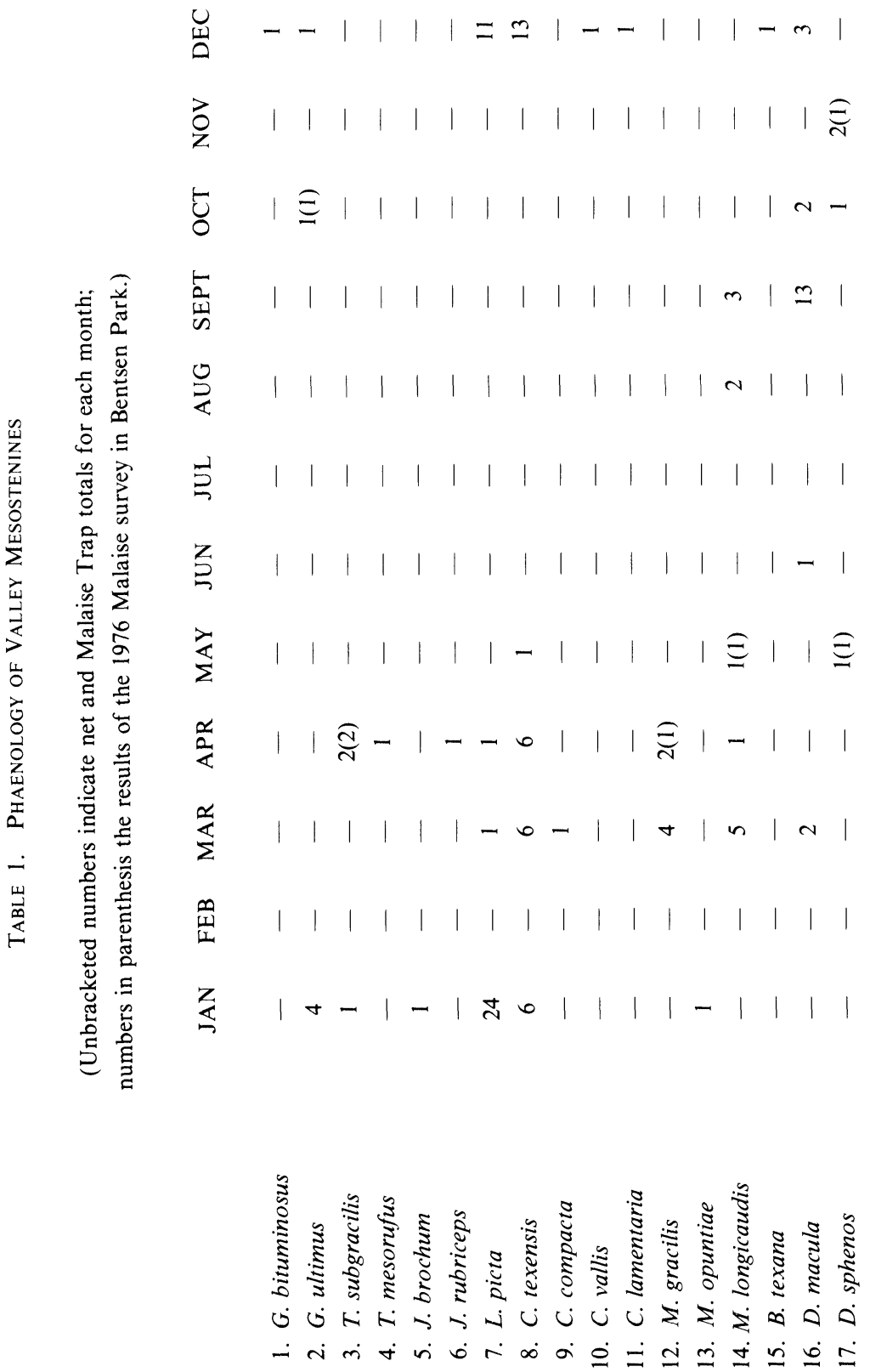


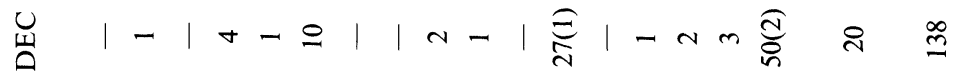

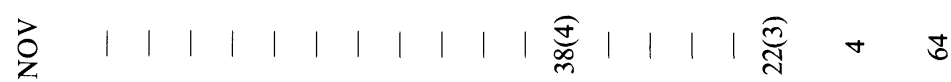

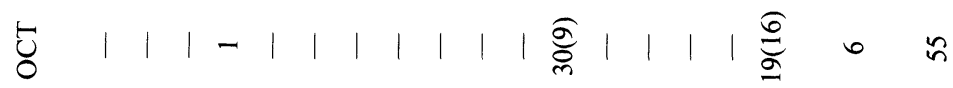

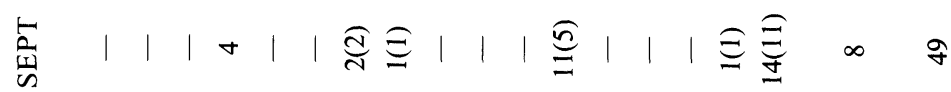

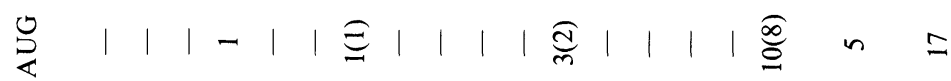

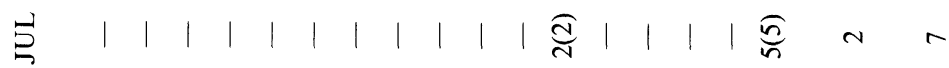

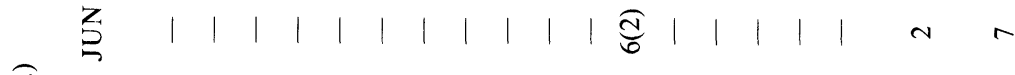

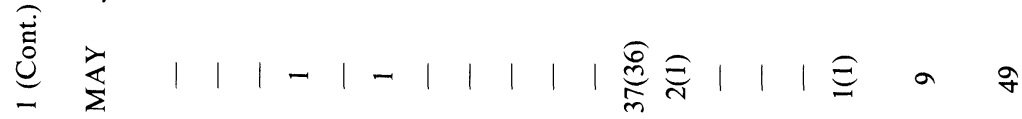

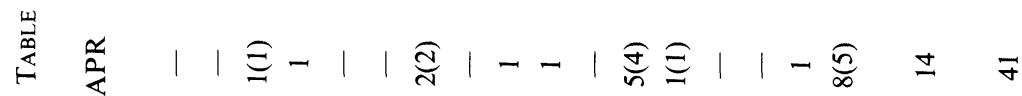

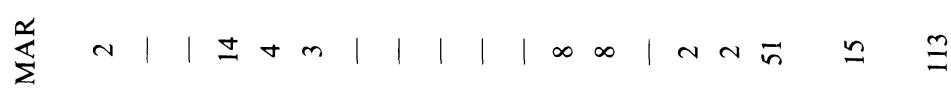

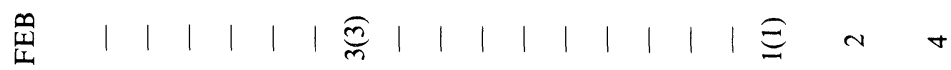

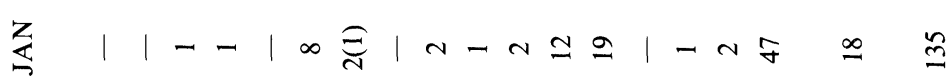

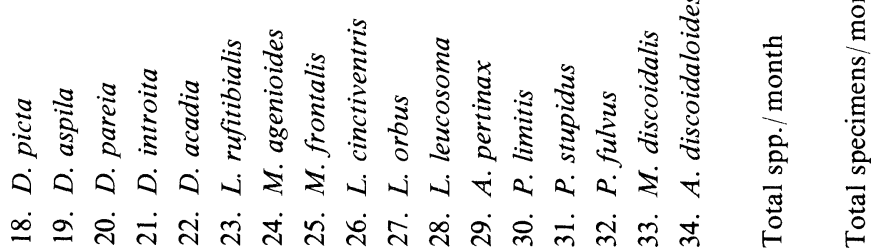


30 of the 34 species collected. Only Trachysphyrus mesorufus (April), Joppidium rubriceps (April), Diapetimorpha sphenos (May, October, November), and Mallochia frontalis (September) were collected exclusively outside that period. Actually, December and January are the optimum months and yielded 273 specimens and 26 species, of which 23 species became most abundant at that time while three others overlapped into December or January from earlier or later maxima (Diapetimorpha macula peaks in September, D. introita in March, and Acerastes pertinax in May and November). Finally, four species peak in late winter or early spring and/or fall but appear to avoid the early winter (Cryptanura compacta in March, Mesostenus gracilis in March-May, M. longicaudis in March-May and August-September, and Diapetimorpha picta in March). Thus there is a large late fall and early winter fauna plus a much smaller exclusively late winter and early spring or spring-fall assemblage, but only minimal activity, and no exclusive species, during the hottest months of June, July, and August. This summer hiatus is demonstrated by the 1976 Malaise survey in Bentsen Park and by exhaustive hand collecting each year in late May and early June and again in the last week of August and the first 9 or 10 days of September. Moisture-loving ichneumonid adults avoid the extreme heat of subtropical summers and attain maximum abundance during the cooler months of the year, when they are less endangered by evaporative water loss and when there are many lepidopterous and coleopterous larvae and pupae to parasitize.

As shown in Table 1, the Bentsen Park Malaise Trap collected a meagre sample of only 12 species and 138 specimens in all of 1976 , and one characterized by mid-spring (April-May) and early fall (September-October) peaks of abundance with relatively few specimens captured in December-March and again in June-July. This result derives from the trap's location in cool, humid woods under the deep shade of a large Pithecellobium. During winter, woodland mesostenines fly in sunny clearings and at the forest edge but, in warmer parts of the year they increasingly seek the protection of deep shade.

Most Valley ichneumonids fly synchronously in climatically favorable periods. My data do not suggest temporal differentiation of closely related species. This agrees with the general observation that ichneumonids, as parasitoids, mainly avoid competition by 
rather minute spatial and size differences in host selection. Each species exploits a series of hosts that may be taxonomically diverse but which occurs in a particular micro-habitat and falls within definite size limits.

Reference to the preceding discussions of abundant species, such as Lanugo picta, Compsocryptus texensis, Acerastes pertinax, and Agonocryptus discoidaloides, shows phaenological variation from year to year as well as from month to month within any given year. Such fluctuations probably result from the variable climate of the Valley (as discussed in the Introduction to this study). Sporadic "killing frosts," which occur about once a decade, devastate some of the Valley's subtropical biota but probably have little effect on ichneumonids. Indeed, mesostenines often become strikingly more abundant in the first warm days after a freeze, suggesting that low temperatures may be necessary to break their diapause. Furthermore, Valley ichneumonids are perfectly adapted to the numerous 4-10 day periods of cloudy, drizzly, cold weather (8-10 degrees C.) triggered in winter by passage of wet cold fronts, since they begin to fly immediately and abundantly within minutes after the sun finally breaks through and temperatures exceed 15 or 16 degrees $C$. Therefore, it is probably the Valley's unpredictable and often lengthy droughts which exercise the most rigorous density independent control on populations of these hygrophile insects.

Finally, we have some data that permit comparison of Valley mesostenine phaenology with that of other New World subtropical communities.

My three year net and Malaise survey of Mesostenini in the northwest Argentine Subandino (Porter, 1975a) produced 21 species and 38 specimens for January, 14 species and 20 species for February, 8 species and 14 specimens for March, 8 species and 12 specimens for April, no records for May, 2 species and 2 specimens for June, 3 species and 3 specimens for July, 1 species and 1 specimen for August, 7 species and 32 specimens for September, 8 species and 20 specimens for October, 7 species and 9 specimens for November, and 17 species and 32 specimens for December. Subandean mesostenines thus peak in summer (December-February), decrease gradually during autumn (March-April), practically disappear in late fall and winter (May-August), and then build up more or less progressively in spring (September-November). The Subandean summer is warm and most of the year's rain falls be- 
tween September and April, while the winter months are almost rainless and bring repeated killing frosts. Rainfall and temperature thus regulate the seasonal cycles of both Subandean and south Texan mesostenines but the annual climatic pattern is totally different in each area, producing an invernal peak in the Valley and a vernal maximum in the Subandino.

During 1973, I maintained a Malaise Trap at General Saavedra near Santa Cruz de la Sierra, Bolivia. Saavedra lies at about 18 degrees S. Lat. and less than $400 \mathrm{~m}$. altitude toward the humid extreme of an ecotone between Chaco scrub and the southernmost Amazon Basin rainforest. My trap was in wet forest under deep shade of cecropias, palms, philodendrons and other "tropical" flora. Monthly Malaise records for Saavedra include 6 species and 8 specimens for January, 3 species and 4 specimens for February, 3 species and 3 specimens for March, (April sample lost), 4 species and 8 specimens for May, 8 species and 9 specimens for June, (July sample lost), 19 species and 35 specimens for August, 5 species and 11 specimens for September, 5 species and 6 specimens for October, 9 species and 18 specimens for November, and 2 species and 4 specimens for December. Furthermore, hand collecting at Saavedra in July yielded 41 species and more than 100 specimens of Mesostenini. This fauna consequently peaks during mid-winter and is much scarcer at other times of the year, showing considerable phaenologic resemblance to the Valley fauna. I have no weather data for Saavedra but infer from its flora that the area receives at least $1500 \mathrm{~mm}$. of rain per year. Summer is the warmest and wettest season but all months have significant precipitation and the winter, although relatively dry, is punctuated repeatedly by cold fronts that may bring 5-10 days of persistent drizzle. July and August temperatures range from nightly lows of 10-15 degrees $C$. to daily highs of around 30 degrees $\mathrm{C}$. but cold fronts may bring minima of 3 degrees $\mathrm{C}$. with mid-day maxima of no more than 12 degrees C. Summer temperatures probably show an average daily range of 25-38 degrees C. The Saavedra climate thus is a little warmer and much wetter than that of the Valley but shows much the same type of variation from month to month and, evidently, has a rather similar effect on the ichneumonids under its control.

Habitat SElection

Of the 34 Valley mesostenine species collected, 21 were taken only in partly to densely shaded woods with considerable under- 
growth and particularly in areas covered by Serjania vines. Of these, five occurred exclusively in Salix-Celtis-Fraxinus gallery woods (Cryptanura compacta, $C$. vallis,. C. lamentaria, Bicristella texana, and Diapetimorpha picta) while the other 16 generally inhabited not only gallery woods but also the Celtis lindheimeri- $C$. pallida association, Pithecellobium thickets, and other comparatively dense types of woods. Perhaps significantly, of the five species limited to gallery woods, all but Diapetimorpha picta are tropical forms unrecorded north of the Valley. Some or all of these thus really may prove restricted to the narrow zone of slightly warmer and much more humid micro-climate immediately along the Río Grande.

Semi-open fence rows and woods-edges yielded eight species: Joppidium brochum, Lanugo picta, Compsocryptus texensis, Diapetimorpha introita, D. acadia, Listrognathus rufitibialis, Pachysomoides fulvus, and Agonocryptus discoidaloides. Only one of these, J. brochum, appeared exclusively in this habitat. $A$. discoidaloides also was found abundantly in deep woods while $D$. acadia was collected both in deep woods and open fields. The other five species were shared with open fields only.

Open sunny, weedy, or grassy places provided nine species: Gambrus bituminosus, Joppidium rubriceps, Lanugo picta, Compsocryptus texensis, Mesostenus longicaudis, Diapetimorpha introita, D. acadia, Listrognathus rufitibialis and Pachysomoides fulvus but only $G$. bituminosus, J. rubriceps, and $M$. longicaudis were taken exclusively from this kind of habitat. It should be noted that the one specimen of $G$. bituminosus occurred in a sandy area near the Río Grande and that bituminosus in other parts of its range also seems associated with river banks, lake shores, and sea shores.

With regard to other habitats, Trachysphyrus mesorufus was the only mesostenine found in xeric Celtis pallida-Condalia obovata scrub and Mesostenus opuntiae the single species collected in the even drier Prosopis-Opuntia association.

The Valley mesostenine fauna thus includes an exclusively or primarily sylvan component of 21 species plus a smaller series of 12 species that shows a variably marked preference for drier and more open habitats. Logically, the Neotropic element predominates in humid situations while the Sonoran genera are conspicuous in and mostly restricted to woods-edge or field habitats. However, the Neotropic genus Diapetimorpha shows differentiation into both 
habitats, with $D$. introita and $D$. acadia mostly in woods-edges and fields and the other five species confined to woods.

Finally, it should be emphasized that few, if any, Valley mesostenines show definite association with an individual plant species or plant community. Mesostenines generally are so versatile in host selection that each one may occur in almost any physically suitable environment with appropriate vegetation structure, irrespective of the taxonomic composition of the local flora.

\section{DIVERSITY}

The first component of diversity is richness or number of taxa inhabiting a particular region. In this study, I have reported 18 genera and 35 species of Mesostenini from the Valley. As already noted, that number agrees rather well with faunas of other arid Middle and South American localities, such as the Peruvian Coastal Desert, with 10 genera and 31 species, or the Argentine Subandino, with 10 genera and 33 species. All these habitats are too xerothermic for optimum mesostenine radiation and contain only a moderate amount of niche space in their simply stratified herbaceous and shrub or herbaceous, shrub, and small tree layers. On the other hand, humid, multilayered subtropical and tropical forests may have seven or eight times the number of mesostenine species present in even nearby deserts. For example, the north Argentine wet forests, Selva Tucumano-Boliviana and Selva Misionera, of which the former in places practically interdigitates with the Subandino, have yielded in 10 years of net and Malaise collecting 40 genera and 237 species of mesostenines. I do not yet have similar data for the northeast Mexican wet forests, which extend along the Sierra Madre Oriental to within $200 \mathrm{~km}$. of the Lower Río Grande Valley, but the fact that five days' hand collecting in a humid ravine at Cola de Caballo near Monterrey (31 May-4 June 1974) produced 12 mesostenine genera (Glodianus, Lymeon, Rhinium, Toechorychus, Cryptanura, Bicristella, Polycyrtus, Messatoporus, Cestrus, Joppidium, Listrognathus, and Baltazaria) suggests that the difference in mesostenine richness between these localities and south Texas eventually will prove similar to that already documented between the Argentine Subandino and its nearby subtropical forests.

A second component of diversity is the apportionment of indi- 
viduals among species, often referred to as evenness or equitability. As shown by the following data as to number of specimens collected and percent of total collection, the Valley mesostenine fauna has two extremely common species, six that may be considered moderately scarce, and 26 which are rare to very rare:

1. A. discoidaloides $-230,34.4 \%$

2. A. pertinax $-179,27.7 \%$

3. L. picta $-37,5.5 \%$

4. P. limitis - $34,5.1 \%$

5. C. texensis $-32,4.8 \%$

6. D. introita $-27,4.0 \%$

7. L. rufitibialis - $22,3.3 \%$

8. D. macula - $21,3.1 \%$

9. M. longicaudis $-11,1.6 \%$

10. M. agenioides $-10,1.5 \%$

11. M. discoidalis - $9,1.3 \%$
12. G. ultimus $-8,1.2 \%$

13. M. gracilis $-6,0.9 \%$

14. D. acadia $-5,0.7 \%$

15. L. cinctiventris $-5,0.7 \%$

16. P. fulvus $-5,0.7 \%$

17. D. sphenos $-4,0.6 \%$

18. L. orbus $-3,0.4 \%$

19. T. subgracilis $-3,0.4 \%$

20. D. pareia $-2,0.3 \%$

21. D. picta $-2,0.3 \%$

22. L. leucosoma $-2,0.3 \%$

Each of the 12 mesostenines not listed above was collected only once during my five year survey, so that $35 \%$ of this community consists of very rare species.

Partially similar equitability data emerge from my three year study of mesostenines in the northwest Argentine Subandino. Here, 12 of the 33 species collected $(36 \%)$ were represented by a single specimen each, so that the percent of very rare species in the Subandino and the Valley faunas is almost identical. However, of the other 21 Subandean species, two each accounted for $15 \%$ of the total number obtained, 1 for $11 \%, 1$ for $7.1 \%, 1$ for $5.9 \%, 2$ for $4.7 \%$ each, 1 for $4.1 \%$, 2 for $2.9 \%$ each, 3 for $2.4 \%$ each, 5 for $1.8 \%$ each, and 2 for $1.2 \%$ each. The Subandean fauna thus has greater equitability than the south Texan in that specimens are apportioned more evenly among the commoner species. Here the two most abundant species, Trachysphyrus doddi and Basileucus sp., together account for 26 specimens each or $30 \%$ of all specimens obtained, while the two most common Valley mesostenines make up $62.4 \%$ of the total for their region. Moreover, mesostenines in general are much rarer in the Subandino than in the Valley. The entire Subandean sample was only 169 specimens (56 per year), while that from the Valley totalled 679 specimens (135 per year). Thus the Subandean fauna is numerically small and composed entirely of scarce to very rare species while the south Texas fauna is numerically larger and contains several genuinely common mesostenines. 
It would be desirable to compare equitability figures for the semiarid Valley and the arid Subandino with data from a comparable long-term survey of mesostenines in some optimum Neotropic wet forest habitat. Although complete information of this type is not yet available, results of my 10 month 1973 Malaise project at General Saavedra, Bolivia may be taken as fairly typical for a humid forest community. At Saavedra, 27 (64\%) of the 42 species trapped were represented by one specimen each, so that there are almost twice as many very rare species at Saavedra as in the Subandino or south Texas. Of the additional 15 Saavedra mesostenines, 1 accounted for $10.4 \%$ of the total number obtained, 1 for $9.4 \%, 2$ for $7.3 \%$ each, 1 for $4.1 \%, 3$ for $3.1 \%$ each, and 6 for $2.1 \%$ each. This fauna thus shows even more equitability of commoner species than the Subandino. The two most abundant Saavedra mesostenines, Diapetimorpha sp. 3 and Agonocryptus sp. 1, together account for 10 and 9 specimens respectively, or only $20 \%$ of all specimens obtained. On the other hand, 96 specimens were trapped at Saavedra during 10 months and this shows much greater overall abundance than the Subandino records (56 specimens per year by Malaise Traps and net), being roughly comparable to my 12 month Bentsen Park Malaise catch of 138 specimens. The Saavedra fauna thus is numerically large but composed entirely of scarce to very rare species.

We can only speculate why evenness shows such marked differences among the three mesostenine communities studied. Saavedra with its many rare species has a benign, thermically and pluvially rather stable climate and the trap employed there was situated in a large patch of undisturbed wet forest, Such environments, where severe physical stress is absent, traditionally are supposed to accommodate large numbers of species in a complex variety of niches determined mainly by selective pressure of interspecific competition. Under these circumstances, reproductive success is less important than niche differentiation for avoidance of competition and many groups are represented by many species, each one of which may be relatively uncommon. Toward the other extreme of the equitability scale, stressed environments have fewer species, some of which are rare since they exist at the limits of their ecological tolerance while others may be disproportionately abundant because some special adaptation allows them to survive the burden of the stress, so that they flourish in a context of minimal compe- 
tition. On the other hand, drastically stressed habitats, where the main selective pressure is toward mere survival, may have few species, none of which is outstandingly abundant. The arid Subandino, with its relict mesostenine populations surviving in scattered humid refugia, doubtless approximates this last model. Finally, the Lower Río Grande Valley, because of its moderately large fauna including many scarce and two superabundant species, seems consistent with the penultimate case. Here the main natural stress is rather low and very irregularly distributed rainfall but to this are added the potent anthropogenic factors of habitat destruction and pesticide contamination. Very little natural flora remains in the Valley and the existing parks and wildlife refuges are surrounded by heavily sprayed citrus groves, truck farms, and other crop systems. Under these conditions, it is not surprising that a few exceptionally tolerant species, such as Agonocryptus discoidaloides, which can thrive in disturbed as well as natural areas, have attained unusually high abundance.

\section{REFERENCES}

Cameron, P.

1886. Biologia centrali-americana Insecta. Hymenoptera. Vol. 1, p. 1-466.

Cushman, R. A.

1930. New species of ichneumon-flies and taxonomic notes. U. S. Natl. Mus. Proc. 76(25): 1-18.

1931. Notes on ichneumon-flies of the genus Polycyrtus. U. S. Natl. Mus. Proc. 78(14): 1-62.

ODUM, E. P.

1971. Fundamentals of Ecology. Third Edition, p. 1-574. W. B. Saunders. PORTER, C. C.

1974. A new Trachysphyrus of the Planosae group from Florida. Florida Entomologist 57(3): 331-335.

1975a. Relaciones zoogeográficas y origen de la fauna de Ichneumonidae (Hymenoptera) en la provincia biogeográfica del Monte del Noroeste Argentino. Acta Zoologica Lilloana 31(15): 175-252.

1975b. Mesostenini of the Peruvian Coastal Desert. In press in National Geographic Research Reports for 1975.

Raven, P. H. \& Axelrod, D. I.

1975. History of the Flora and Fauna of Latin America. American Scientist 63(4): $420-429$.

TOWNES, H. K.

1962. Ichneumon-flies of America north of México: 3. Subfamily Gelinae, Tribe Mesostenini. Bull. U. S. Natl. Mus. 216, pt. 3, p. 1-602.

1966. A catalogue and reclassification of the Neotropic Ichneumonidae. Mem. Amer. Ent. Inst. 11: 1-367.

1972. A light-weight Malaise Trap. Entomological News 83(9): 239-247. 

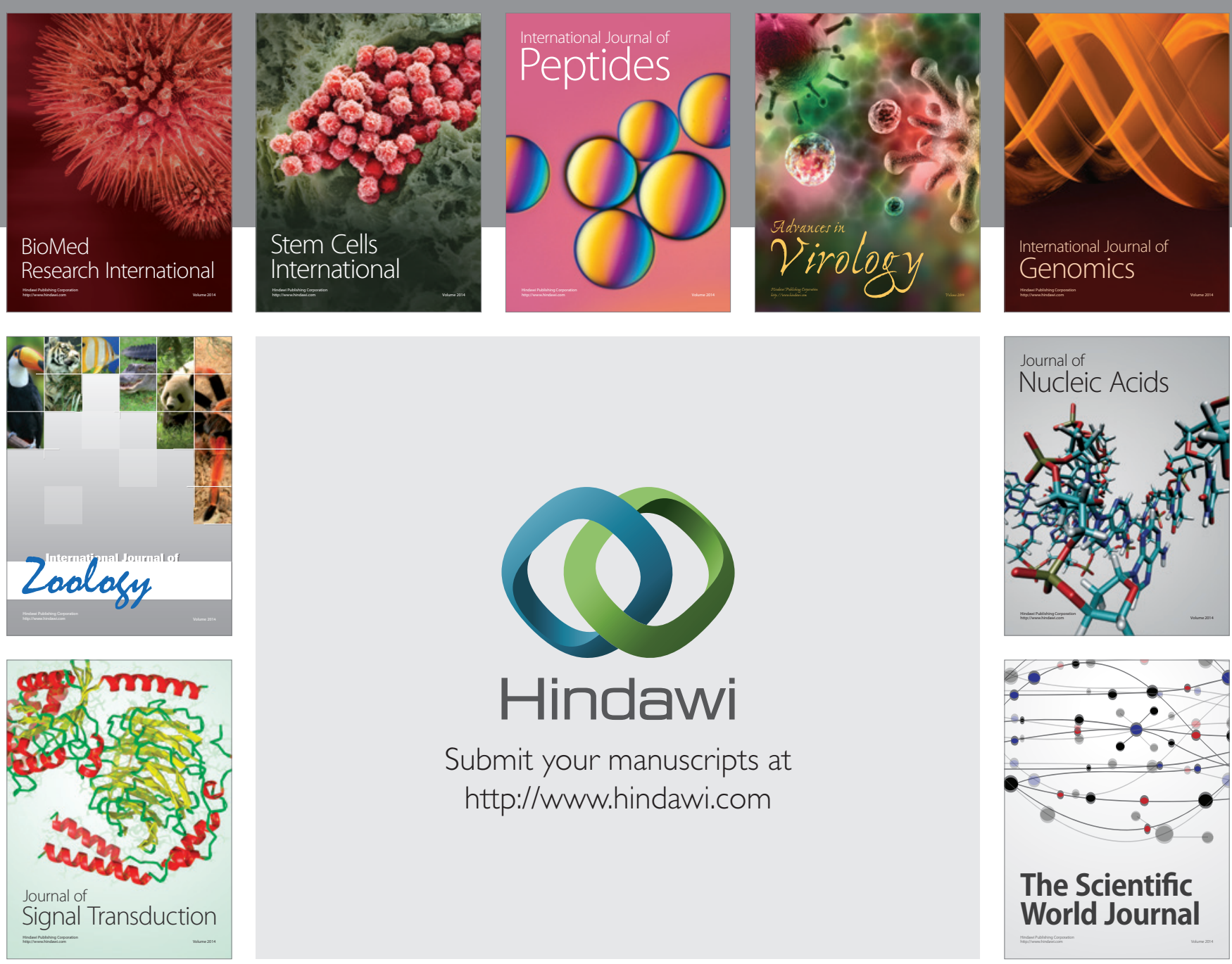

Submit your manuscripts at

http://www.hindawi.com
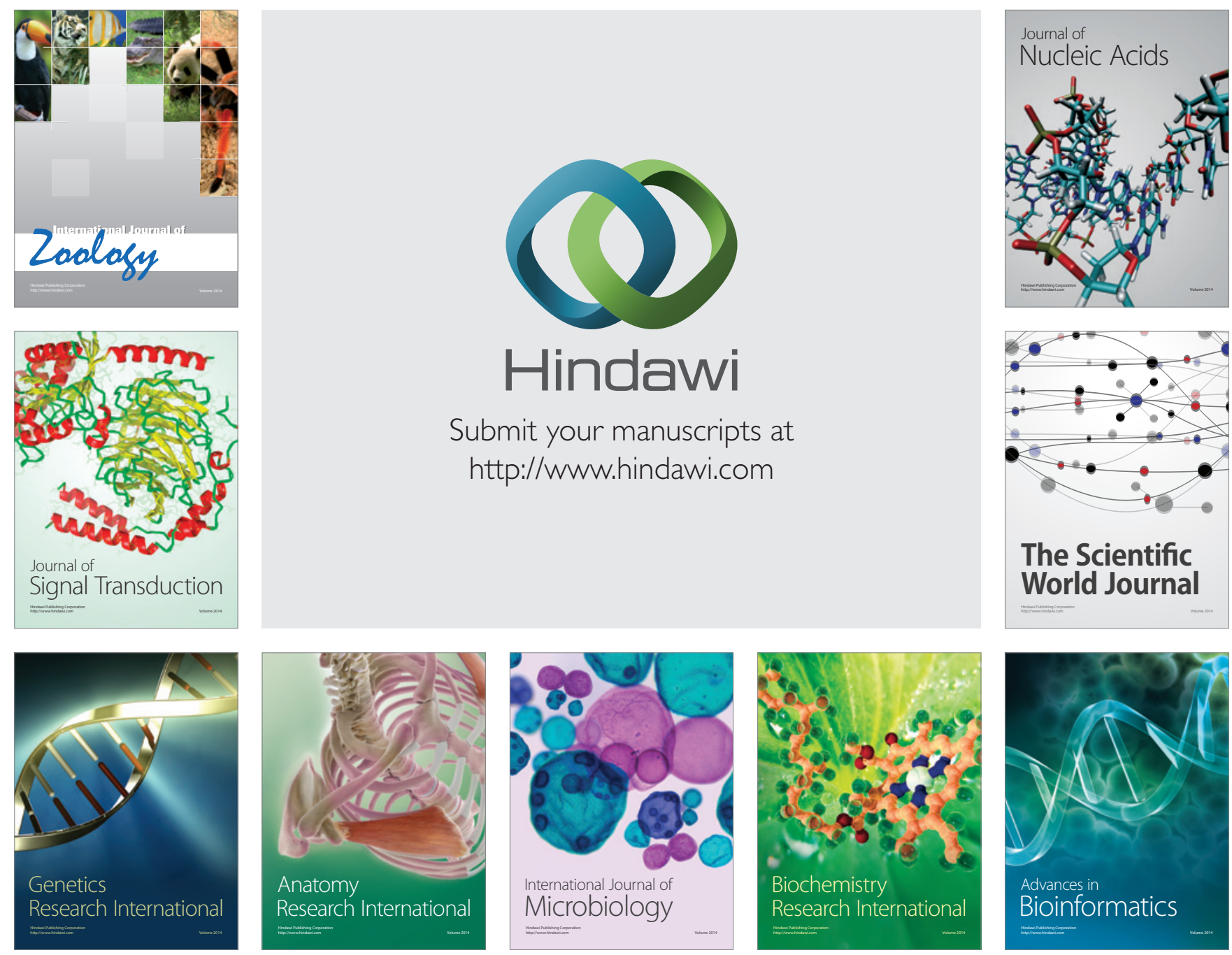

The Scientific World Journal
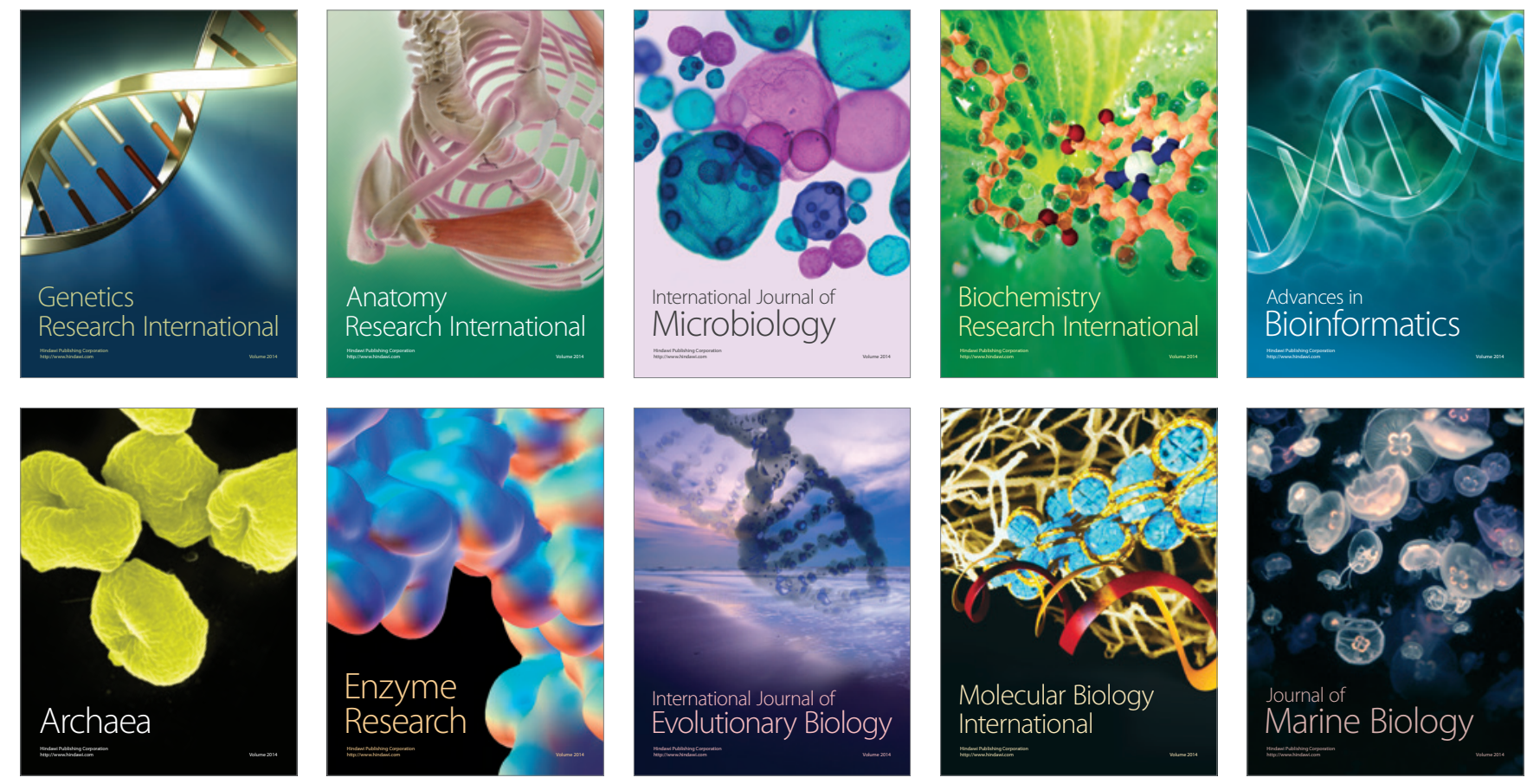